FACULDADE DE ECONOMIA, ADMINISTRAÇÃO, CONTABILIDADE E CIÊNCIA DA INFORMAÇÃO E DOCUMENTAÇÃO - FACE PROGRAMA DE PÓS-GRADUAÇÃO EM ADMINISTRAÇÃO - PPGA CURSO DE ESPECIALIZAÇÃO EM GESTÃO DE PESSOAS MUDANÇAS NA PERCEPÇÃO DOS ENVOLVIDOS 


$$
\begin{gathered}
\text { Universidade de Brasília - UNB } \\
\text { PPGA - Programa de Pós-Graduação em Administração }
\end{gathered}
$$

Curso de Especialização em Gestão de Pessoas

\title{
"A implantação de projetos socioambientais e a resistência a mudanças na percepção dos envolvidos"
}

\author{
LÍLIAN MARIANA DE OLIVEIRA FERNANDES BARBOSA
}

\author{
Prof ${ }^{a}$ Dra. Catarina Cecília Odelius \\ Coordenadora
}

Prof ${ }^{a}$ Msc. Josivania Silva Farias

Orientadora

\footnotetext{
"Trabalho apresentado em cumprimento às exigências acadêmicas parciais do curso de pósgraduação lato sensu em Gestão de Pessoas para a obtenção do grau de Especialista."
}

Brasília - DF

2009 
Barbosa, Lílian Mariana de Oliveira Fernandes Barbosa

A implantação de projetos socioambientais e a resistência a mudanças na percepção dos envolvidos. Lílian Mariana de Oliveira Fernandes Barbosa

Monografia - Pós-Graduação em Gestão de Pessoas.

Brasília- DF, Agosto de 2009.

Área de Concentração: Gestão de Pessoas - Mudança Organizacional.

Orientadora: Prof ${ }^{a}$. Msc. Josivania Silva Farias.

1. Projetos Socioambientais. 2. Mudança Organizacional. 3. Aceitação e obstáculos à mudança. 
Primeiramente, meus agradecimentos eternos a Deus, pela vida e por todas as oportunidades de crescimento tanto profissional quanto pessoal que me concedeu. À minha orientadora, pelas horas dedicadas ao meu auxílio, pelo acompanhamento diferenciado, pelas exigências necessárias e pela descontração nos momentos de tensão. A equipe da LAF - Empresa de Serviços Hospitalares Ltda, Hospital Brasília, pela gentileza em participar da confecção desta pesquisa e pelo fornecimento dos dados. Aos meus pais pelo apoio em mais esta etapa cumprida em minha vida, por investirem em mim, pelo carinho e dedicação de sempre. Ao meu irmão, pelas constantes orientações de leituras para meu crescimento profissional. Ao meu namorado, pela compreensão, paciência, carinho, companheirismo e por me fazer uma pessoa muito mais feliz. Aos amigos que me incentivaram e me apoiaram em tudo. Aos colegas da V Turma do Curso de Especialização em Gestão de Pessoas da UnB que dividiram comigo essa conquista. 


\section{RESUMO}

Esta pesquisa visou verificar a existência de resistência à mudança organizacional no processo de implantação de projetos socioambientais em uma organização hospitalar privada. Na pesquisa de caráter qualitativo, por meio de entrevistas estruturadas aos colaboradores da organização, buscou-se verificar se os envolvidos possuíam resistência à mudança. As informações coletadas foram analisadas com base na fundamentação teórica deste estudo. Os resultados indicaram que a maioria dos entrevistados considera importante a implantação de projetos socioambientais no ambiente organizacional e os principais obstáculos culturais e organizacionais para a implantação destes projetos apresentados foram: falha na comunicação; falta de acompanhamento dos projetos; falta de recursos e incentivos e desvio de foco ou de objetivos em relação ao projeto. Os entrevistados citaram contribuições importantes que devem ser providenciadas quando da implantação destes tipos de projetos.

1. Projetos socioambientais. 2. Mudança Organizacional. 3. Aceitação e obstáculos à mudança. 


\section{SUMÁRIO}

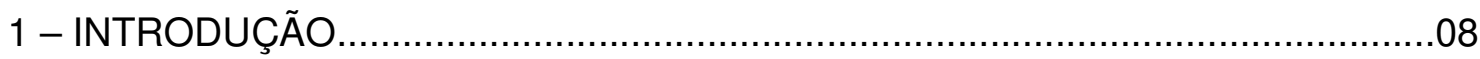

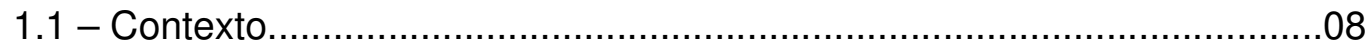

1.2 - Problema de pesquisa.........................................................................

1.3 - Objetivo geral................................................................................

1.4 - Objetivos específicos.....................................................................10

1.5 - Justificativa

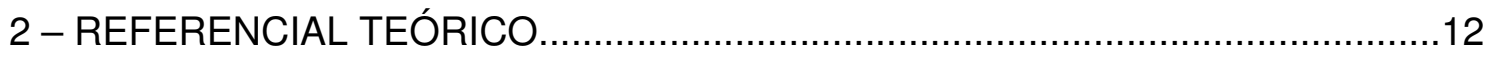

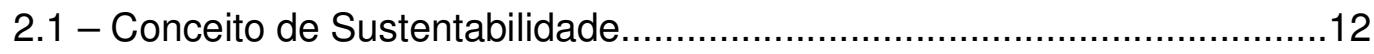

2.1.1 - Responsabilidade Social..................................................15

2.1.2 - Responsabilidade Ambiental..................................................16

2.2 - Cultura Organizacional.......................................................................16

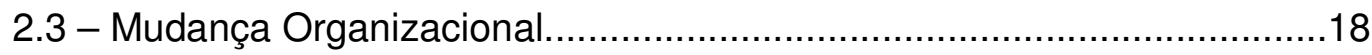

2.4 - Aceitação da Mudança...................................................................21

2.5 - Resistências e obstáculos à mudança...............................................23

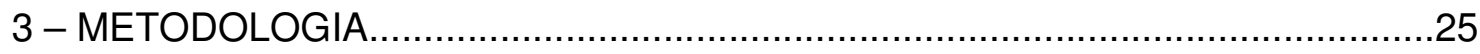

3.1 - Procedimentos e técnicas utilizadas.................................................25

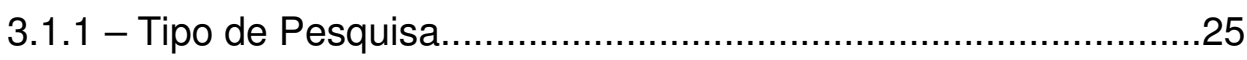

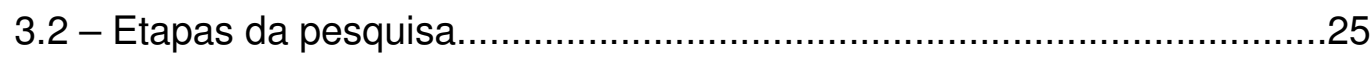

3.2.1 - Elaboração de entrevista semi-estruturada..............................25

3.2.2 - Seleção dos sujeitos.............................................................26

3.2.3 - Procedimento de coleta dos dados.........................................26

3.2.4 - Procedimento de análise dos dados.......................................27

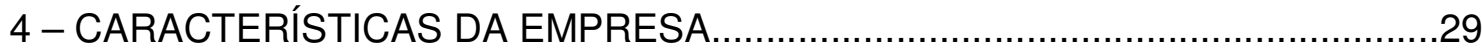

4.1 - Instituição, propósitos e porta da organização........................................29 


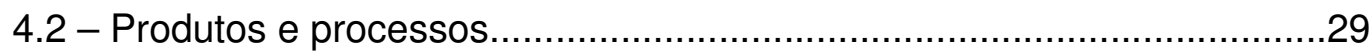

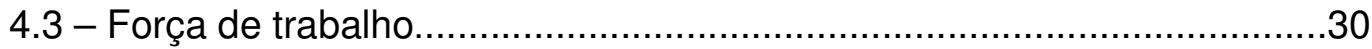

4.4 - Clientes e mercado............................................................................

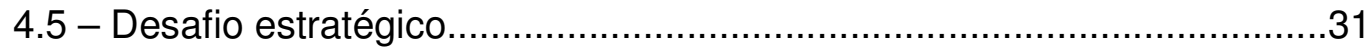

5 - APRESENTAÇÃO E ANÁLISE DE RESULTADOS............................................

5.1 - Perfil dos entrevistados......................................................................

5.2 - Apresentação dos projetos socioambientais.......................................32

5.2.1 - Importância dos projetos para os entrevistados........................35

5.2.2 - Obstáculos culturais à implantação dos Projetos

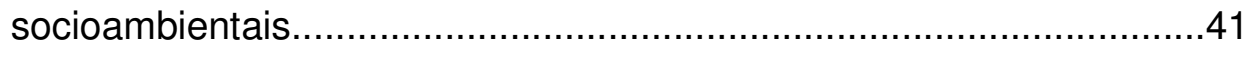

5.2.3 - Obstáculos organizacionais à implantação dos Projetos

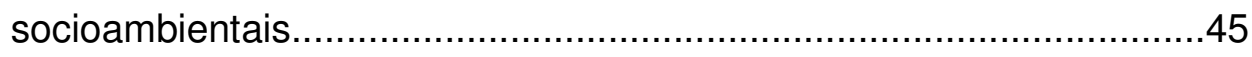

6 - CONCLUSÕES

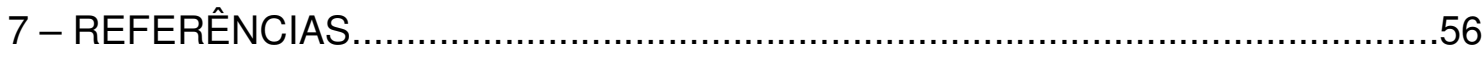

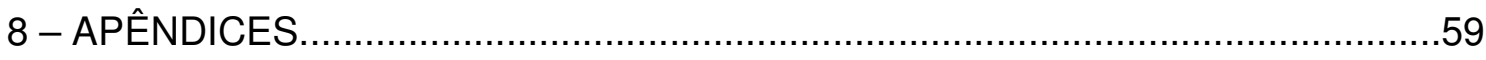

Apêndice 1 - Roteiro de entrevista estruturada............................................59

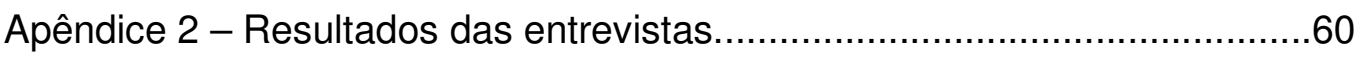

DESCRIÇÃO DOS ENTREVISTADOS.............................................60

TRANSCRIÇÃO DAS ENTREVISTAS...........................................61 


\section{INTRODUÇÃO}

\subsection{Contexto}

A organização locus de estudo deste trabalho, está em fase de implantação de projetos socioambientais em seus processos, a fim de contribuir para um melhor desenvolvimento da sociedade e do meio-ambiente. É uma empresa de serviços hospitalares que busca atualização constante de seus processos com visão de mercado, no sentido de implantar o que for preciso para a melhoria de seu atendimento e para o bem-estar dos seus colaboradores. Este ano, portanto, visa ampliar essa visão em benefício não só de seus clientes e colaboradores, mas também da sociedade, a qual também é cliente em potencial.

A proposta de implantação de projetos socioambientais partiu da Diretoria da empresa, sendo inserida no Planejamento Estratégico. A idéia de haver uma estrutura específica para o desenvolvimento desses projetos socioambientais também está relacionada à importância que se tem dado atualmente às empresas que investem não só em benefício próprio, mas promove o desenvolvimento também da sociedade, por meio de auxílios financeiros e afetivos; prestações de serviços comunitários, trabalhos voluntários em instituições carentes, dentre outros, em nível social. Há também uma preocupação com o desenvolvimento ambiental, por ser uma organização voltada para a saúde, preocupando-se com a elevada geração de resíduos hospitalares, buscando o aproveitamento de materiais recicláveis e a redução de poluentes no meio-ambiente e a plantação de árvores.

Por trás deste investimento, há também a visão comercial, o marketing envolvido nestas questões. As empresas, não só hospitalares, estão investindo mais nesses projetos e, assim, exercendo sua responsabilidade socioambiental. Os clientes, ao conhecerem a empresa e o seu caráter socioambiental, poderão auxiliar na divulgação espontânea a outros clientes e atuar como voluntários, multiplicando o número de clientes e, consequentemente, incrementando o lucro do hospital. Outras empresas com o mesmo intuito poderão unir-se como parceiras nesses projetos sem custos adicionais, cada uma contribuindo com uma parte do processo. Enfim, são vários os intuitos do hospital com a implantação de projetos com esta filosofia ou orientação para o socioambiental. 
Por ser um investimento que apresenta custos elevados, surge o questionamento se realmente terá efeito positivo após a implantação.

Busca-se, dessa forma, verificar antecipadamente a opinião dos colaboradores da empresa sobre a importância da implantação desses projetos; o interesse pelos projetos da empresa; a participação de voluntários para movimentar essa iniciativa, o sucesso que poderia ser alcançado com tudo isso, dentre outros.

E como todo processo de implantação de novos projetos gera mudanças organizacionais, torna-se necessário avaliar como são percebidas estas implantações; como são aceitos os projetos; se a organização está preparada para a resolução de possíveis problemas e resistências advindas desse momento de mudança.

\subsection{Problema}

Uma questão importante a ser verificada durante a implantação de qualquer novidade em uma empresa é a questão de quanto essa mudança organizacional influenciará os demais processos da empresa, no cotidiano dos colaboradores voluntários, isto é, a repercussão que haverá, se será positiva ou negativa.

É justamente a resposta para esta questão que culminou a necessidade da realização desta pesquisa. Afinal, os envolvidos no processo de implantação de projetos socioambientais na organização hospitalar estudada apresentam resistência às mudanças implantadas?

Caso as resistências encontradas na pesquisa comprometam o sucesso dos projetos socioambientais, no momento da implantação, será necessário abordar questões que auxiliem no processo de aceitação da mudança pelas pessoas. $\mathrm{Na}$ verdade, o intuito maior dessa pesquisa é antecipar o conhecimento de qualquer interferência que possa prejudicar o processo de implantação para, ao obter essas informações, tomar as decisões cabíveis a fim de facilitar este processo.

Se as resistências encontradas não forem solucionáveis, isto acarretará em um problema. A empresa deve estar preparada para receber possíveis posicionamentos contrários e questionamentos acerca dos objetivos do projeto; o que isso influenciará na vida dos voluntários; qual o interesse do hospital com essa iniciativa e outras questões que podem surgir. 
A coordenação dos projetos socioambientais necessita de colaboradores voluntários para auxiliar na condução de cada projeto e o sucesso dessa condução vai depender da participação e da atuação dos voluntários. Portanto, se não houver interesse dos voluntários, como serão realizadas as ações relativas aos projetos? Provavelmente não serão realizadas, acarretando em projetos implantados sem continuidade. Se a resistência for mais significativa do que a aceitação, isto será mais um determinante a ser trabalhado antes da implantação, a fim de conscientizar não só os que interessados, mas também os que desconhecem o trabalho socioambiental.

\subsection{Objetivo geral}

Verificar na percepção dos envolvidos a existência de resistência à mudança na implantação de projetos socioambientais.

\subsection{Objetivos específicos}

- Levantar os projetos socioambientais da organização;

- Verificar a importância da implantação de projetos socioambientais em organizações na percepção dos envolvidos;

- Verificar aspectos culturais que podem criar obstáculos à implantação de projetos inovadores que refletem na mudança organizacional;

- Verificar aspectos organizacionais que podem criar obstáculos à implantação de projetos inovadores que refletem na mudança organizacional. 


\subsection{Justificativa}

A decisão de se implantar projetos socioambientais nos processos da organização foi tomada pela diretoria da empresa, devido à grande valorização que se tem dado a este tipo de iniciativa nas empresas. Atualmente, a maioria das organizações visa atuar não só na sua atividade fim, mas também buscam ações relacionadas à sociedade e ao meio ambiente.

Esse comprometimento da organização com os meios social e ambiental influencia diretamente na visão que a sociedade tem sobre o negócio e os valores da empresa. Uma organização hospitalar preocupada com o meio ambiente e com a sociedade gera uma repercussão bastante satisfatória para o hospital no mercado, será um diferencial no momento da escolha do hospital que freqüentará.

Porém, para que o processo de implantação dos projetos seja eficaz e os mesmos tenham continuidade, não basta uma aceitação somente da sociedade, é necessário que os colaboradores da empresa também apóiem esta idéia e se sintam participantes do processo, engajados nos processos voluntariamente, por compartilharem do mesmo ideal.

Dessa forma, torna-se essencial fazer uma avaliação prévia sobre a importância que esses projetos socioambientais têm para os envolvidos, a fim de se ter uma previsão da aceitação das mudanças nos processos ou se há resistência a mudanças, o que pode dificultar a implantação, divulgação e desenvolvimento dos projetos.

Caso seja verificada forte resistência a mudanças por meio das informações colhidas nesta pesquisa juntamente aos envolvidos, é pertinente desenvolver, antecipadamente a implantação, uma estratégia visando mudança de opinião; acolhimento dos voluntários; treinamentos com foco em responsabilidade social e ambiental, demonstrando a importância da participação de cada colaborador voluntário; a fim de engajá-los a este processo. 


\section{REFERENCIAL TEÓRICO}

Neste capítulo são desenvolvidos os conceitos de sustentabilidade, cultura organizacional, mudança organizacional, aceitação e resistência à mudança, isto é, os conceitos julgados essenciais para o entendimento do processo de implantação de novos projetos socioambientais na visão do colaborador, o maior envolvido neste processo.

\subsection{Conceito de Sustentabilidade}

A valorização crescente das empresas que praticam a sustentabilidade organizacional, isto é, que focam em seus processos as responsabilidades socioambientais e as questões éticas; tem gerado uma constante preocupação das organizações com a vida no futuro, com o destaque advindo dessa atitude perante as demais empresas e a sociedade, bem como um investimento cada vez maior na execução e manutenção destes projetos.

Em meados da década de 1980 foi lançado o conceito do desenvolvimento sustentável. Após a Conferência das Nações Unidas sobre o Meio Ambiente e Desenvolvimento (Rio-92), um dos maiores desafios gerados foi construir instrumentos para sua mensuração, a fim de manter a ação, subsidiar o acompanhamento e a avaliar o progresso alcançado rumo ao desenvolvimento sustentável (TAYRA; RIBEIRO, 2006).

Segundo Baumgarten (2002), há no planeta um sistema desigual de trocas, por exemplo, os incontroláveis efeitos perversos das novas tecnologias sobre o ambiente, os riscos para a humanidade, as formas predatórias de utilização do trabalho e da natureza. Estes elementos sinalizam para a urgência em desenvolver estratégias sócio-político-ambientais sustentáveis e em incorporar princípios éticos ao desenvolvimento econômico e técnico-científico.

Esta preocupação é de extrema importância, segundo Baumgarten (2002), pois o homem atua desenvolvendo novas tecnologias úteis e que facilitam sua vida, mas que, conseqüentemente, agridem o meio ambiente. Dessa forma, tornou-se necessário utilizar sua inteligência também para desenvolver estratégias sustentáveis. O homem começou a dedicar-se a encontrar mecanismos para evitar 
ou amenizar esse efeito, a fim de manter a sua sobrevivência e a de seus descendentes.

No final do século $X X$ surgiu a preocupação sobre a conduta intelectual dos cientistas. Os pesquisadores responsabilizam-se agora pela esperança da solução de problemas e impasses surgidos em decorrência do avanço da ciência. (BURSZTYN, 2001). Baumgarten (2002, p. 39) acrescenta que "a aposta na possibilidade de um desenvolvimento sustentável no Brasil tem como fundamento uma nova concepção de ciência na qual os princípios da solidariedade e da dignidade humana substituem os princípios do produtivismo e do cálculo racional”.

A necessidade em preocupar-se com estas questões acarreta o estudo de um conceito muito mais amplo, a sustentabilidade, enfocando as responsabilidades social, ambiental e ética. São várias as definições que abordam esse conceito, porém, todas elas se resumem principalmente na menor utilização de recursos naturais a fim de evitar a escassez dos mesmos e propor novas formas de utilização ou reaproveitamento destes recursos.

Segundo Fontes (2003, p. 161), a "sustentabilidade é um conceito emprestado do ecodesenvolvimento. Refere-se à possibilidade de um desenvolvimento sem prejuízo aos recursos existentes, quer dizer, uma possibilidade de completar o ciclo de reprodução mantendo-se relativamente estáveis as condições ambientais".

A sustentabilidade, porém, não engloba somente a preservação ambiental, conforme já citado, envolve também ações sociais voluntárias visando o bem-estar da comunidade. Fontes (2003, p.162) descreve esta visão na afirmação: "uma associação voluntária com alto grau de envolvimento com a comunidade de origem - e que, portanto, garante respostas favoráveis a ações de mobilização de recursos para empreender ações coletivas - seria a princípio uma associação com grandes possibilidades de empreender ações sustentadas".

Hoje a empresa que visa somente o lucro e os processos rotineiros, isto é, permanece estagnada visando somente interesses próprios e não se adapta às necessidades do mercado, esquecendo-se da questão ambiental e social e de como identificar meios para atuar em benefício do próximo, está perdendo espaço para aquelas que cultivam estes valores organizacionais. A idéia refere-se à capacidade de a empresa obter lucro sem sacrificar os recursos de suas pessoas, da comunidade e do planeta. 
Esta iniciativa deve acontecer individualmente, conforme defende Vecchiatti (2004), por meio da conscientização e sensibilização dos indivíduos da empresa. Cada um tem responsabilidade neste processo e toma consciência disso ao refletir sobre a vida dos futuros seres vivos e habitantes do planeta, principalmente seus descendentes.

"Apesar de raramente pensadas em termos de sustentabilidade, as políticas culturais são de suma importância, porque suas ferramentas de intervenção geralmente se aproximam da subjetividade humana. (...) À medida que o indivíduo se conscientiza da repercussão de seus atos nas gerações futuras e se preocupa com isso, desenvolve-se uma preocupação através das gerações capaz de enxergar uma responsabilidade comum. Para alcançar esse estado ideal, entretanto, o desenvolvimento cultural deve partir do reconhecimento dos cenários nos quais os atores sociais interagem, constroem espaços mudam os valores e os olhares sobre a vida em sociedade". (VECCHIATTI, 2004, p. 93).

Enfim, há a necessidade de que todos os indivíduos estejam engajados nos projetos, sintam-se pertencentes ao grupo e de causas e objetivos compartilhados. As políticas culturais devem contribuir para gerar pertenças a partir do resgate da auto-estima individual e coletiva. Sem a auto-estima não é possível o desenvolvimento humano com a sociedade (FARIA, 1999).

Nesse sentido, buscando acompanhar a evolução do conhecimento científico e do desenvolvimento tecnológico, as organizações vêm investindo em colaboradores que possuam uma visão de futuro, com o objetivo de desenvolver produtos e/ou processos diferenciados. São necessárias pessoas criativas, com condições de enfrentar as mudanças de maneira original e inovadora, para o desenvolvimento sócio-cultural e econômico como para a construção do futuro (construção de novos conhecimentos, ciência e a tecnologia). 


\subsubsection{Responsabilidade Social}

O termo responsabilidade social nas organizações há alguns anos vem sendo discutido e o resultado disso foi a mudança no conceito, a concepção de caridade e altruísmo abre espaço para um combinado entre responsabilidade social e estratégia organizacional, visando vantagem competitiva (SERPA; FOURNEAU, 2007). Segundo Ashley; Coutinho; Tomei (2000, p. 1), "o conceito de responsabilidade social é intrinsecamente interdisciplinar, multidisciplinar e associado a uma abordagem sistêmica, focada nas relações entre stakeholders associados direta ou indiretamente ao negócio da empresa".

Para Serpa; Fourneau (2007), alguns dos princípios da visão socioeconômica da responsabilidade social são o foco nos lucros de longo prazo para o negócio; melhoria da imagem da organização perante a sociedade; menor regulamentação governamental para o negócio; incorporação de maiores obrigações sociais para o negócio e promoção de melhor ambiente para todos.

Kang (apud ASHLEY; COUTINHO; TOMEI, 2000, p. 11) acrescenta que "as corporações são obrigadas a cumprir suas responsabilidades sociais e morais antes de tentarem maximizar seus lucros, sendo um meio eficiente e efetivo de controle social e uma base para a confiança nas relações humanas e organizacionais". Bower (apud SERPA; FOURNEAU, 2007) compartilha da idéia de Kang quando considera a responsabilidade social como uma obrigação dos administradores das empresas de adotarem orientações, tomarem decisões e seguirem linhas de ação compatíveis com os valores e os fins da sociedade.

Ashley; Coutinho; Tomei (2000) afirmam ainda que a prática da empresa e a mídia ressaltam exclusivamente a instrumentalização da responsabilidade social corporativa como auxílio na formação da reputação da empresa, a fim de adquirir competitividade no mercado. Este conceito requer a aplicabilidade das práticas não reduzidas à racionalidade instrumental, mas a um novo modelo mental de relações sociais, econômicas e políticas. Dessa forma, a performance da empresa é avaliada pelo equilíbrio existente entre estas relações.

Conforme visto acima, há uma dificuldade na definição dos valores e dos fins de cada sociedade e quais as linhas de ação empreendidas (SERPA; FOURNEAU, 2007). 


\subsubsection{Responsabilidade Ambiental}

Segundo Portilho (apud RUSCHEINSKY, 2008), para se pensar em um modelo de sociedade sustentável é necessário verificar o relacionamento entre produção e consumo, entre cidadania e práticas sociais. No foco ambiental, há muitos conflitos ambientais devido à degradação e à exaustão de recursos naturais.

As organizações, principalmente aquelas que geram um grande percentual de resíduos, estão promovendo uma redução nesta prática por meio de novos projetos e buscando evitar ao máximo o uso abusivo dos recursos naturais. Portilho (apud RUSCHEINSKY, 2008), em sua obra, não foca na crítica ao consumo supérfluo, mas alerta para os limites do consumo, a delimitação dos recursos naturais e a busca de uma racionalidade ambiental.

Segundo Ashley; Coutinho; Tomei (2000, p. 11), "as propostas de consumo sustentável restritas à esfera individual são limitadas, limitantes e desagregadoras. As ações de caráter coletivo podem ampliar as possibilidades de ambientalização e politização das relações de consumo, contribuindo para a construção da sustentabilidade e para a participação na esfera pública".

\subsection{Cultura Organizacional}

O termo cultura, advindo da antropologia social, foi estudado no final do século $\mathrm{XIX}$ e início do século $\mathrm{XX}$, quando os estudiosos observaram que os modos de vida de cada sociedade diferenciavam-se entre si e entre outras regiões, isto é, cada sociedade possuía características comuns e particularidades. O conceito então foi criado para representar as qualidades de qualquer grupo humano específico, transmitidas de geração em geração (TAVARES, 1996).

Segundo Tavares (1996), na organização, surgem também grupos de indivíduos que formam a cultura organizacional, manifestada por meio da resistência às mudanças, por incompatibilidade de valores, crenças, mitos e tabus enraizados na empresa. Além disso, a cultura organizacional manifesta-se por meio de padrões de comportamento ou pelo estilo de uma organização assumido pelos funcionários e que são transmitidos aos novos funcionários da empresa. 
Shein (apud TAVARES, 1996, p.2), define cultura organizacional como "o modelo dos pressupostos básicos, que determinado grupo tem inventado, descoberto ou desenvolvido no processo de aprendizagem para lidar com os problemas de adaptação externa e integração interna. Uma vez que os pressupostos tenham funcionado bem o suficiente para serem considerados válidos, são ensinados aos demais membros como a maneira correta para se perceber, se pensar e sentir-se em relação àqueles problemas".

Oliveira (apud TAVARES, 1996, p.2), percebe a cultura organizacional como um conjunto de valores e crenças existentes na organização e comportamentos individuais e coletivos decorrentes das normas da organização, isto é, a cultura está enraizada e a mudança não acontece rapidamente. Segundo Bastos (2001, p.5), "a cultura, enquanto um poderoso e sutil padrão de comportamento organizacional, pode facilitar ou dificultar a implementação de mudanças".

Segundo Zanelli; Borges-Andrade; Bastos (2004, p. 439), as culturas "são fenômenos espontâneos, conservadores e ocultos, de difícil identificação e alteração intencional", e sugerem resistência aos mínimos gestos que evoquem mudança, descontinuidade e instabilidade.

Dessa forma, portanto, tem-se que a cultura não pode ser modificada, somente ampliada ou resignificada, alterando-se conceitos considerados essenciais nos modelos mentais dos portadores da cultura (ZANELLI; BORGES-ANDRADE; BASTOS, 2004).

De acordo com Zanelli; Borges-Andrade; Bastos (2004, p. 410), "a cultura é um processo acumulativo que resulta do aprendizado obtido da totalidade da experiência histórica das gerações antecedentes. As peculiaridades desse processo podem restringir ou facilitar os comportamentos criativos e inovadores dos seres humanos". 


\subsection{Mudança organizacional}

Para Hernandez e Caldas (2001), as mudanças organizacionais acontecem para equiparar a crescente competição, cumprir as leis e regulamentações, introduzir novas tecnologias ou atender às variadas necessidades e expectativas dos clientes e parceiros.

Para Wood (apud MONTEIRO; VENTURA; CRUZ, 1999), a mudança no contexto da organização está relacionada a alterações no comportamento humano, na padronização do trabalho e nos valores advindos destas modificações. Dessa forma, segundo ele, enfrentar com sucesso o processo de mudança depende do gerenciamento das pessoas, mantendo alto nível de motivação e evitando decepções no processo. Acrescenta ainda que, em um processo de mudança organizacional, o maior desafio é promover mudança nas pessoas e, conseqüentemente, na cultura organizacional e não somente nos recursos e tecnologia. Com a renovação dos valores, a partir da mudança na cultura organizacional, é possível obter destaque perante as demais organizações, ou seja, vantagem competitiva.

Os fatores essenciais para uma mudança cultural, segundo Wood (apud MONTEIRO; VENTURA; CRUZ, 1999), são: a mudança deve ser baseada nas forças e valores da organização; ter participação em todos os níveis; acontecer de forma holística, relacionando-se com estrutura, estratégia, sistemas de recompensa e de controle; ter apoio da alta gerência para que se torne um processo contínuo e ser planejada à longo prazo e executada em etapas.

Segundo Monteiro, Ventura; da Cruz (1999, p.14), "toda mudança implica algum sacrifício e é sempre cercada por incertezas". O foco maior de resistência em um processo de mudança de cultura organizacional talvez não seja pelo fato da mudança em si, mas de como ela é gerenciada e, conseqüentemente, como é gerenciada a própria cultura da organização.

Para Jabes (apud LEAL; SILVA, 2000, p.1), "a mudança organizacional implica na transformação de um sistema de ação, na qual são alteradas as relações entre os participantes de uma organização, bem como seus mecanismos de regulação". Ainda segundo o autor, este processo não é simples e exige grande capacidade de influenciação dos participantes. Por isso uma das variáveis a serem 
consideradas em um processo de mudança é a satisfação, refletindo no engajamento das pessoas envolvidas.

Grandes transformações sociais, econômicas, tecnológicas e políticas vêm trazendo novos cenários para o mundo do trabalho. Os fenômenos da globalização, terceirização, os novos modelos de gestão, os avanços tecnológicos e a automação têm provocado significativas mudanças nas organizações e nas formas de trabalho. Essas mudanças vêm trazer 0 aumento da competitividade, e apenas a diferenciação nos processos e produtos de uma organização vai acompanhar essa evolução (MONTEIRO, VENTURA; DA CRUZ, 1999).

Segundo Souza e Castro-Lucas (2007), empreendedorismo é um conjunto de conhecimentos, habilidades e atitudes que possibilitam qualquer indivíduo a desempenhar com sucesso e de forma criativa e inovadora, quaisquer atividades em que ele se engaje.

Conforme Schumpeter (1998), o empreendedorismo é a busca de novas direções, do diferencial competitivo e de novas conquistas, associado à inovação, na medida em que sua essência está na percepção e aproveitamento de oportunidades de negócio, no desejo de fundar empreendimentos, de utilizar recursos de uma nova forma, e na alegria de criar, de fazer coisas e de exercitar a energia e a engenhosidade.

Sendo assim, Ohta e Ohta (2004) dizem que, enquanto a criatividade cuida da concepção de novas ideias, a inovação envolve a concretização e a aplicação dessas novas ideias. Alencar (1996 apud OHTA e OHTA, 2004) define inovação como o processo de introduzir, adotar e implementar uma nova idéia em resposta a um problema percebido, transformando uma nova idéia em algo concreto.

Já Bruno-Faria (2003) considera a inovação como o resultado da implantação de ideias, processos, produtos e serviços originários dos indivíduos e/ou grupos na organização, bem como da introdução de novas tecnologias e outros novos elementos originados fora da organização, considerados com valiosos para os resultados da organização e/ou bem estar das pessoas que nela trabalham.

Para eficácia e efetividade de um projeto empreendedor é necessário que se conheça o ambiente em que se está inserido, conhecer o mercado em que se está querendo entrar ou manter, preocupar-se com o ônus de tal projeto e sempre superar as expectativas, premissa básica para que haja um diferencial competitivo. 
A implementação de uma nova idéia à um problema, deve está baseada no conjunto de processos e/ou atividades que participam do desenvolvimento de um produto ou serviço da organização, chamada de cadeia de valor.

Segundo Rocha; Borinelli (2007, p. 146), partindo-se do pressuposto de que as atividades devem ser foco da gestão para se conquistar e conservar vantagens competitivas, e sabendo-se que elas são executadas em uma seqüência, formando uma cadeia, chega-se à idéia de cadeia de valor. Para esses autores, "a cadeia de valor é uma seqüência de atividades que se inicia com a origem dos recursos e vai até o descarte do produto pelo último consumidor (ROCHA; BORINELLI (2007, p. 149)." A análise de cadeias de valor serve para subsidiar o processo de gerenciamento estratégico, pois permite compreender e agir sobre a estrutura patrimonial, econômica, financeira e operacional das suas principais atividades, processos e entidades. O objetivo maior é conquistar e manter vantagem competitiva.

Desse modo, para se pôr em prática um projeto de inovação é necessário conhecer a cadeia de valor e o negócio da organização, avaliar o estágio das competências disponíveis, se necessário deve-se capacitar tais colaboradores e organizá-los para se comprometerem com tal projeto, encontrar o tipo mais adequado de gestão da inovação e pôr em prática os projetos empreendedores.

Para que a mudança aconteça, segundo Tavares (1996), é necessário um estudo prévio dos elementos da cultura organizacional (valores, crenças, tabus, mitos, normas, comunicação formal e informal), pois eles condicionam e direcionam o comportamento das pessoas e grupos.

Segundo Bastos (2001), cerca de cinqüenta por cento das publicações levantadas no período de 1983 a 1993 com a temática cultura organizacional são na área de enfermagem. Estas publicações indicam a importância da cultura na implantação de mudanças na área de saúde.

Bastos (2001) ainda complementa que para se implantar novos programas em instituições de saúde é de fundamental importância na tentativa de solucionar problemas analisar as características estruturais e históricas das instituições de saúde, bem como dos símbolos materiais, verbais e comportamentais.

Chambel e Sousa (2007), as mudanças nas organizações ocorrem visando responder às ameaças, desafios e oportunidades e melhorar seu desempenho e 
perenidade. Dessa forma, tem-se a gestão da mudança como um papel fundamental nesse processo. Quando uma mudança é proposta, segundo Huy (apud CHAMBEL; SOUSA, 2007), é necessário encontrar meios de desencadear receptividade cognitiva e emocional nos participantes do processo organizacional, isto é, a mudança tem de ser legítima e aceita; desenvolver a mobilização ou empenho dos participantes em ações e objetivos comuns; avaliar os resultados das ações, o que possibilita uma aprendizagem a partir dos resultados e busca constante de melhoria.

Fairhurst e Sarr (apud CHAMBEL; SOUSA, 2007), mostraram em seus estudos que a maneira com que as organizações constroem a mudança influencia as respostas dos empregados e Shapiro, Buttner e Barry (apud CHAMBEL; SOUSA, 2007), também concluíram que o modo como os empregados interpretam as razões da mudança influencia as suas reações a ela.

Moura (2002) acredita que, mesmo que várias pesquisas apontem fracassos nos resultados de programas de transformação empresarial, percebem-se esforços empresariais para a melhoria contínua dos diversos processos da organização. Além disso, acrescenta Zanelli; Borges-Andrade; Bastos (2004), o êxito da mudança depende vitalmente da coerência entre o discurso dos principais dirigentes e as práticas resultantes.

\subsection{Aceitação da Mudança}

Bies e Shapiro (apud CHAMBEL; SOUSA, 2007), estudaram a reação dos colaboradores à presença ou ausência de mudança implantada pelo gestor e verificou-se que a comunicação dos motivos das decisões pelo gestor é essencial para o aumento da aceitação da mudança. Outros estudos mostraram que as justificativas adequadas para as razões da implantação de mudanças dadas pelo gestor diminuíam a presença de sentimentos de descontentamento com as decisões tomadas.

Shapiro e Bies (apud CHAMBEL; SOUSA, 2007), no entanto, verificaram em seus estudos que não era necessário somente comunicar os motivos da mudança, mas apresentar motivos legítimos, a fim de evitar sentimentos de traição e desconfiança, conflitos e retaliações. Bies (apud CHAMBEL; SOUSA, 2007), dessa 
forma, argumentou que a confiança na gestão influenciava de maneira positiva a credibilidade e legitimidade da razão da mudança, isto é, os colaboradores que confiam na gestão, aceitam melhor os motivos e justificativas da mesma, além de influenciar também na percepção de justiça ou injustiça nesse processo de mudança.

Rousseau (apud CHAMBEL; SOUSA, 2007, p.4) acrescenta que "é na relação dos empregados com a organização que se formam as suas interpretações sobre as ações, essencialmente porque esta relação é um produto da história de vida dos empregados com a organização". Pfeffer (apud CHAMBEL; SOUSA, 2007) complementa que a qualidade das relações de trabalho durante o processo de mudança torna-se um papel importante para a aceitabilidade e para o envolvimento do colaborador.

Outro fator importante para que haja aceitação da mudança é compreender que é essencial que haja consenso nos grupos; expressão de confiança ao abordar temas relacionados às mudanças; configuração do processo de mudança como construção de habilidades; disponibilização de tempo para que os participantes da organização possam assimilar e consolidar a mudança e incentivo para que se adaptem e compreendam a concepção essencial da mudança como ajuste às necessidades atuais (ZANELLI; BORGES-ANDRADE; BASTOS, 2004). 


\subsection{Resistências e obstáculos à mudança}

Schein (apud ZANELLI; BORGES-ANDRADE; BASTOS, 2004) afirma que as intensas mudanças nos ambientes tecnológico, econômico, político e sociocultural são capazes de transformar as práticas propostas pela empresa em problemas a serem enfrentados.

A resistência à mudança é um dos possíveis comportamentos dos indivíduos que podem surgir durante um processo de mudança. Segundo Pereira (1999), o processo de mudança é bastante complexo e difícil de lidar, pois provoca reações específicas nas pessoas, conscientes ou não e condicionadas por arquétipos, paradigmas e crenças da identidade de cada um.

É necessário compreender, segundo Zanelli; Borges-Andrade; Bastos (2004), que o processo de mudança gera resistência em função de rupturas nos modos até então considerados certos de proceder. Dessa forma, conforme descreve Pettigrew (apud ZANELLI; BORGES-ANDRADE; BASTOS, 2004), é mais viável promover ajustes nas dimensões mais superficiais da cultura do que modificar o núcleo de pressupostos básicos e o sistema de crenças de uma organização.

A forma como é vista a mudança também pode causar ou não resistência por parte dos envolvidos, pois para Motta (1998), esta tem que ser encarada como uma inovação benéfica para a solução de problemas, visando o desenvolvimento da empresa, isto é, tem que ter objetivos claros e expectativas de resultados eficazes. Os colaboradores, portanto, têm que conhecer detalhadamente o processo, para verificarem a utilidade da mudança.

Pereira $(1999$, p.5) acrescenta que "o processo de mudança é sempre de auto-mudança, não é possível mudar uma pessoa se ela não quiser". Dessa forma, tem-se que é necessário que a pessoa tenha um ganho com isso, isto é, a pessoa aceitará melhor a novidade quando a alteração de sua maneira de pensar e agir for maior que a sua satisfação relativa, conforme aborda Motta (1998).

Uma das maneiras de se diagnosticar resistências na organização é o que Moura (2002, p. 54) denomina de "resistência branca", isto é, há uma resistência à mudança por parte dos envolvidos de maneira camuflada, pois dizem acreditar nas propostas, aceitam e pregam os novos conceitos à equipe e, concomitantemente, 
atrasam o alcance de tais melhorias e não são proativos, fazendo com que o discurso não seja condizente com a prática.

Para que haja motivação do empregado na empresa é necessário ficar atento a uma série de fatores, dentre eles, a convergência entre os valores pessoais e organizacionais; pois quando os valores pessoais colidem com os valores organizacionais é possível que as pessoas envolvidas fiquem desmotivadas para cooperar e se comprometer com a organização" (ZANELLI; BORGES-ANDRADE; BASTOS, 2004). É essencial, portanto, buscar um equilíbrio entre os valores pessoais e organizacionais, caso contrário, pode-se configurar em mais um tipo de resistência a mudanças na organização.

Outra forma da resistência se manifestar é a forma com que os dirigentes conduzirão o processo. Segundo Zanelli; Borges-Andrade; Bastos (2004, p. 440), "os dirigentes necessitam pensar como agentes de mudança (...) agir para não repetir procedimentos que deixaram de ser funcionais à organização".

Segundos os autores, o processo de mudança pressupõe, por si só, a existência de ansiedade, comportamentos defensivos e resistência à mudança e, por isso, devem agir de acordo com o que professam, a fim de estimular que os demais participantes da comunidade organizacional confiram credibilidade à realidade social em mudança (ZANELLI; BORGES-ANDRADE; BASTOS, 2004). 


\section{METODOLOGIA}

Por meio da metodologia deste estudo buscou-se investigar se existe resistência à mudança na percepção dos colaboradores da organização. A seguir, são apresentados detalhadamente os passos e a estruturação da pesquisa.

\subsection{Procedimentos e técnicas utilizadas}

Esta pesquisa caracterizou-se por ser de desenho metodológico qualitativo. Com tal procedimento buscou-se verificar se há resistência a mudanças na ótica de envolvidos no processo de implantação de projetos socioambientais na organização, por meio de entrevistas individuais realizadas com os colaboradores da organização.

\subsubsection{Tipo de Pesquisa}

A pesquisa foi realizada em uma organização hospitalar privada do Distrito Federal e o tipo de pesquisa utilizado foi caráter qualitativo.

A pesquisa de caráter descritivo-qualitativo caracteriza-se por considerar o ambiente natural como fonte direta de dados, o pesquisador como instrumento fundamental; o caráter descritivo; a preocupação do investigador com a valorização do significado que as pessoas dão às coisas e à sua vida e o enfoque indutivo, conforme identifica Neves (1996).

\subsection{Etapas da pesquisa}

A pesquisa constituiu-se em quatro etapas: escolha dos sujeitos, realização de entrevista estruturada, coleta dos dados e análise dos dados. Estas etapas foram desenvolvidas durante o período de maio a junho de 2009.

\subsubsection{Elaboração de entrevista estruturada}

A elaboração do roteiro de entrevista estruturada (apêndice 1) baseou-se em perguntas relacionadas à opinião e percepção dos envolvidos; à implantação de projetos socioambientais na empresa; à importância que os mesmos dão a esta 
iniciativa empresarial, bem como ao próprio referencial teórico, que serviu de base para fomentar as questões, a fim de constatar antecipadamente características de um processo de resistência a mudanças nos envolvidos.

\subsubsection{Seleção dos sujeitos}

O quadro de colaboradores, no mês de junho de 2009, compunha-se de 800 colaboradores.

A pesquisa, por ser qualitativa, foi realizada com 12 (doze) colaboradores, escolhidos, segundo o julgamento da pesquisadora, de acordo com acessibilidade, interesse e disponibilidade de participar, bem como sua capacidade de contribuir com o estudo, a fim de se verificar se há mais resistência a mudanças em determinados setores.

Os sujeitos entrevistados, para fim de apresentação e análise dos resultados, foram identificados da seguinte forma: E1, E2, E3, E4, E5, E6, E7, E8, E9, E10, E11 e E12.

Os setores escolhidos foram: CASA (Central de Atendimento e Serviço de Apoio ao cliente); Segurança e Medicina do Trabalho; Educação e Desenvolvimento de Pessoas; Endomarketing; Benefícios; Compras; Departamento Pessoal; Recrutamento e Seleção; Qualidade.

\subsubsection{Procedimento de coleta de dados}

A coleta de dados deu-se por meio das entrevistas estruturadas e individuais, realizadas durante o mês de junho de 2009 e agendadas antecipadamente com cada um dos colaboradores entrevistados.

Utilizou-se um gravador como recurso para gravar as entrevistas para, posteriormente, serem transcritas. 


\subsubsection{Procedimento de análise de dados}

A técnica utilizada para analisar os dados coletados foi análise de conteúdo que, segundo Berelson (1954, apud RICHARDSON, 1999), é uma técnica utilizada em pesquisas para descrever objetiva, sistemática e quantitativamente o conteúdo manifesto da comunicação. Bardin (2004) acrescenta que a análise de conteúdo trabalha a palavra, ou seja, a prática da língua por meio de deduções lógicas e justificadas e se define como um conjunto de técnicas de análise das comunicações, que utiliza procedimentos sistemáticos e objetivos de descrição do conteúdo das mensagens. Estes saberes deduzidos dos conteúdos podem ser de natureza psicológica, sociológica, histórica ou econômica.

$\mathrm{Na}$ análise dos dados desta pesquisa foram consideradas, não somente as respostas dos colaboradores entrevistados, mas também o conteúdo relacionado às respostas, não necessariamente declarado por eles. Para Bardin (2004, p. 39), a intenção da análise de conteúdo é a inferência de conhecimentos, esta considerada como uma "operação lógica pela qual se admite uma proposição em virtude da sua ligação com outras proposições já aceitas como verdadeiras".

Após a análise de conteúdo, os dados foram submetidos a inferências de sentido que, segundo Richardson (1999), é uma das características metodológicas da análise de conteúdo. Para Bardin (2004) a análise de conteúdo possui duas funções: uma função heurística (enriquece a tentativa exploratória e aumenta a propensão à descoberta) e uma função de administração da prova (os dados analisados podem ser submetidos à confirmação ou informação). Portanto, os dados foram interpretados segundo este raciocínio.

A organização da análise de conteúdo foi dividida com base nas orientações de Bardin (2004), em três fases: a pré-análise, a exploração do material e o tratamento dos resultados, a inferência e a interpretação. A fase de pré-análise é realizada primeiramente uma leitura flutuante, isto é, "estabelecer contato com os documentos a analisar e conhecer o texto deixando-se invadir por impressões e orientações", em seguida, a escolha dos documentos, no qual é definido o universo de documentos de análise; a regra da exaustividade, no qual não se pode deixar de fora qualquer um dos elementos por esta ou por aquela razão (dificuldade de acesso, impressão de não-interesse); a regra da representatividade, no qual a 
análise pode ser efetuada por meio de amostra que seja representativa do universo inicial e os resultados são generalizados ao todo; a regra da homogeneidade, no qual os documentos devem ser homogêneos e referirem-se todos a um mesmo tema e a regra de pertinência, no qual é importante verificar se os documentos são adequados como fonte de informação.

A fase de exploração do material consiste essencialmente de operações de codificação, por isso, caracteriza-se por ser longa e fastidiosa. Os resultados brutos devem ser tratados de forma que sejam significativos e válidos, ou "falantes". Após essa fase, é realizada uma síntese e seleção dos resultados, seguida de inferências e interpretações que gerem outras orientações para uma nova análise ou utilização dos resultados de análise com fins teóricos ou pragmáticos (BARDIN, 2004).

Uma operação importante de classificação de elementos constitutivos de um conjunto, por diferenciação ou por reagrupamento com critérios previamente definidos é a categorização, definida por Bardin (2004).

A análise do conteúdo desta pesquisa foi dividida em quatro categorias, a partir dos objetivos específicos da pesquisa:

1. Apresentação dos projetos socioambientais;

2. Importância dos projetos para os entrevistados;

3. Obstáculos culturais à implantação dos projetos socioambientais;

4. Obstáculos organizacionais à implantação dos projetos.

Tem-se, portanto, que cada objetivo específico foi transformado em categoria, definidas a priori, segundo Bardin (2004), por meio do agrupamento de diferentes atitudes em grandes categorias e adição de atitudes valorizadas e atitudes desvalorizadas correspondentes, pode-se gerar um quadro representativo de valores e qualidades individuais. Após esse reagrupamento é realizada a análise categorial, que serve de base para descrever as principais fases de uma análise de conteúdo.

Para Bardin (2004), as atitudes positivas são a prudência reflexiva, energia, otimismo, diplomacia, reserva, exploração das próprias capacidades e boa vontade. As atitudes negativas são impulsividade, desencorajamento, preguiça, fraqueza, espírito crítico e desperdício das próprias forças e capacidades.

Por fim é realizada a análise temática, "rápida e eficaz na condição de se aplicar a discursos diretos e simples (...) é transversal, pois recorta o conjunto das entrevistas através de uma grelha de categorias projetada sobre os conteúdos (BARDIN, 2004, p. 153; p. 175). 


\section{CARACTERÍSTICAS DA EMPRESA}

Este capítulo aborda as principais características da empresa, locus de pesquisa, e está dividido em cinco partes: instituição, propósitos e porte da organização; produtos e processos; força de trabalho; clientes e mercados; e desafios estratégicos, a fim de proporcionar um maior entendimento da pesquisa pelo leitor.

\section{1 - Instituição, propósitos e porte da organização}

O Hospital Brasília (nome fantasia) é uma sociedade por cotas de responsabilidade imitada de capital fechado denominada LAF - Empresa de Serviços Hospitalares Ltda., destinada à prestação de serviços médico-hospitalares.

Inaugurado em 1987, e até 1998 conhecido como Hospital Golden Garden, prestava serviços a um único cliente e parceiro, o convênio Golden Cross. Em 2000, passou a ser administrado pela LAF - Empresa de Serviços Hospitalares Ltda gerando novas e importantes mudanças na organização, tais como:

- Atuação com mais de oitenta (80) convênios entre planos de saúde, seguradoras, cooperativas e autogestão;

- Oferta da melhor assistência médico-hospitalar a custos compatíveis (se possível o menor de seu segmento) sem achatar a margem de lucro; bem como responsabilidade social e ambiental;

- Hospital geral atuando no setor de prestação de serviços hospitalares com predominância epidemiológica em maternidade e procedimentos cirúrgicos neurológicos, ortopédicos e com tendência estratégica de crescimento na área cardíaca e oncológica.

\section{2 - Produtos e processos}

As funções principais de uma organização hospitalar são: cuidar e assistir seus clientes - pacientes dentro da filosofia de humanização que permeia todo processo assistencial, cuidar dos familiares dos nossos clientes - pacientes para que, ao deixarem as nossas dependências, sintam-se encantados. 
O processo assistencial tem como finalidade cuidar do cliente-paciente, no tempo adequado ao tratamento de cada condição de saúde, e ao término da sua permanência no hospital, reintegrá-lo ao convívio familiar e social, dentro das possibilidades clínicas e terapêuticas. Portanto, os resultados esperados ("produtos") são:

- Cliente-paciente cuidado e assistido, e;

- Família "encantada".

\section{3 - Força de trabalho}

1) A força de trabalho é denominada genericamente de Colaborador.

2) Os requisitos de segurança e saúde para as pessoas que compõem ou não a força de trabalho atendem ao prescrito nas normas regulamentadoras do Ministério do Trabalho, sendo as de maior ênfase a NR 32 - Segurança e Saúde no Trabalho em Serviços de Saúde (Portaria MTE №. 485 de 11/11/2005) e as NR-07 (PCMSO) e NR-09 (PPRA).

3) Adicionalmente e proativamente o HOBRA desenvolve ações (preventivas e preditivas) que superam a legislação em vigor, de forma a proporcionar a toda força de trabalho condições de segurança e saúde excepcionais, entre essas práticas destacam-se: O programa SOL, indicadores de acidentes de trabalho, atuação da CIPA e treinamentos.

\section{4 - Clientes e mercados}

O principal mercado do Hospital Brasília é o Distrito Federal que abrange Brasília e suas regiões administrativas. A área de atuação do HOBRA é definida corporativamente em coerência com a estratégia de expansão do GRUPO ESHO, abrangendo atualmente todo o Centro-Oeste.

O Hospital Brasília vem ampliando sua área de atuação e o seu mercado passou a ser regional, motivada pela premiação que o considerou como o melhor hospital do Centro-Oeste por dois anos consecutivos. Hoje há internação de pacientes oriundos de outras unidades federativas como, por exemplo: Mato Grosso, Mato Grosso do Sul, Tocantins, Pará, Bahia, dentre outros. Esses clientes-pacientes 
procedentes da faixa econômica A, demandam procedimentos de alta complexidade, notadamente cirurgias cardiovasculares, neurocirurgias e tratamentos oncológicos.

\section{5 - Desafios Estratégicos}

O principal desafio estabelecido no Planejamento Estratégico é realizar a expansão geográfica (mercado) do grupo, para tanto deve maximizar a lucratividade das suas atividades de forma a garantir a sustentabilidade do Grupo com recursos próprios.

\section{APRESENTAÇÃO E ANÁLISE DE RESULTADOS}

Este capítulo apresenta o perfil dos entrevistados; os principais resultados das entrevistas e análise do conteúdo das mesmas. As entrevistas encontram-se na íntegra no apêndice 2 desta pesquisa.

\section{1 - Perfil dos entrevistados}

Para uma melhor apreciação das opiniões dos entrevistados, faz-se necessário conhecer os perfis dos profissionais que participaram das entrevistas.

Foram entrevistadas 12 pessoas, sendo 4 homens e 8 mulheres. Dentre elas, 6 trabalham na área administrativa e de negócio da empresa e 4 estão lotadas na área assistencial e relacionamento com clientes.

A pesquisa envolveu entrevistados com tempo de empresa de 15 dias a 5 anos e a faixa etária variou de 21 a 37 anos. 


\section{2 - Apresentação dos projetos socioambientais}

A organização estudada possui vários programas e projetos socioambientais, visando o bem-estar da sociedade e do meio-ambiente. Dentre eles, pode-se citar: o Programa de Reciclagem e Gerenciamento de Resíduos na parte ambiental e o Voluntariado Luz na parte social. Seguem abaixo os demais programas e projetos com esta visão.

Programa de Reciclagem e Gerenciamento de Resíduos: Programa mantido através de campanhas, informativos e reuniões, onde os colaboradores são estimulados a reciclar o lixo do trabalho e de sua casa. Com uma competição saudável, o colaborador que trouxer mais lixo reciclável é premiado. Desde a implantação deste projeto a reciclagem tem sido uma atividade de sucesso da empresa na área de comprometimento assistencial. A educação e cultura mostradas dentro do ambiente de trabalho criam nas pessoas um nível extra de comprometimento com a sociedade e o meio-ambiente.

Voluntariado Luz: Os colaboradores são dispensados no dia em que há a campanha voluntária (páscoa, agasalho, dia das crianças, natal) para ajudarem no trabalho social na instituição acolhida pelo hospital nos horários necessários. Os voluntários interessados se inscrevem no setor de Educação e Desenvolvimento de Pessoas com a Psicóloga Social. Dentre as atividades, pode-se citar: doações e visitas em creches, asilos e orfanatos. O colaborador tem o suporte do TH para melhor aproveitamento e desenvolvimento do trabalho. Esta iniciativa enfoca a qualidade de vida das pessoas envolvidas, como um caminho para construção de uma sociedade mais humana e mais feliz.

Programa Em dia com o Planeta: Este programa tem como objetivo fomentar a responsabilidade socioambiental no hospital, investindo, desta forma, na preservação e reposição das condições de vida saudável no Planeta. Com isto, atua- 
se de maneira decisiva para a neutralização de $\mathrm{CO}^{2}$, e a consequente redução do aquecimento global. A idéia é responsabilizar-se não somente com o plantio das mudas, mas também com o crescimento e manutenção das mesmas. Para isso, cada cliente internado que obtiver alta no hospital colaborará com o reflorestamento das áreas de preservação ambiental e desmatamento da seguinte forma: para cada cliente uma muda será plantada.

Projeto Bolsa de Estudos: Projeto de Concessão de Bolsa de Estudos para os colaboradores do Hospital que atendem as condições e pré-requisitos necessários, interessados em realizar cursos que possam ser aproveitados pelo hospital, nos variados setores.

Junior Achievement: O Hospital Brasília tem parceria com a Junior Achievement no desenvolvimento de jovens para o mercado de trabalho. Mensalmente o hospital investe financeiramente e auxilia com o necessário para a manutenção do projeto. São beneficiados cerca de 800 jovens com este auxílio.

Casa do Menino Jesus: Este projeto refere-se a um auxílio prestado a Casa do Menino Jesus. Mensalmente o hospital investe um valor à Casa do Menino Jesus correspondente a despesas como mensalidade escolar, material escolar, cesta básica, inglês, transporte, material didático, lanche na escola.

Brasília Teen: Programa voltado para adolescentes filhos de colaboradores da empresa, com idade entre 12 e 14 anos. Os temas abordados voltam-se, para o desenvolvimento pessoal e as futuras escolhas dos jovens, entre eles: a sexualidade na adolescência, maternidade e paternidade precoce, escolha da melhor profissão, responsabilidade social, objetivo de vida e auto-estima. Posteriormente, pode-se ampliar o público alvo para os adolescentes da sociedade.

Curso de Idiomas: A empresa oferece bolsa para os colaboradores que demandam este conhecimento. As aulas de inglês podem ser feitas na empresa em horário de almoço ou na escola especializada. O curso ainda proporciona descontos para os dependentes de nossos colaboradores. 
Universidade Corporativa: Este programa visa atender as demandas estratégicas, alinhando-se aos valores e missão da empresa com o propósito de resultados, por meio do desenvolvimento das competências do corpo funcional do hospital e de nossos parceiros.

Curso de Gestantes: O Curso de Gestante do Hospital Brasília é aberto para seus clientes externos e internos. São três dias de palestras informativas destinadas às gestantes ou esposas de colaboradores. Realizado todo mês e com duração de três horas por dia. Os temas buscam preparar a mãe e a família para as mudanças que envolvem a chegada do bebê.

Campanhas internas: Campanha do Agasalho; Campanha para Asilos; Campanha Dia das Crianças; Campanha de Natal; Campanha de Arrecadação de Alimentos.

Acompanhamento dos afastados: Projeto Social que visa acompanhar o colaborador que está afastado por licença a saúde, onde são realizadas visitas periódicas na casa do colaborador afastado, pela Psicóloga Social da empresa, a fim de dar assistência e ajudar o colaborador a regressar para o trabalho. 


\subsection{1 - Importância dos projetos para os entrevistados}

Sobre a importância dos projetos socioambientais na percepção dos envolvidos, percebeu-se que, por meio da análise do conteúdo das falas, os projetos são bastante valorizados por todos, como é possível verificar na fala do E2, quando interrogado se apoiava a iniciativa dos projetos socioambientais:

"Com certeza, é importante, pois demonstra que não estamos sendo egoístas ao pensar somente em benefício próprio, mas também em benefício da comunidade e do meio-ambiente".

Ou ainda na fala do E10:

"Tais práticas só trazem benefícios a todos os envolvidos, (...) é um ciclo que pode crescer por si só, desde que todos os envolvidos façam a sua parte".

Este mesmo participante, E10, citou uma importante visão, a qual se pode esquematizar em um ciclo:

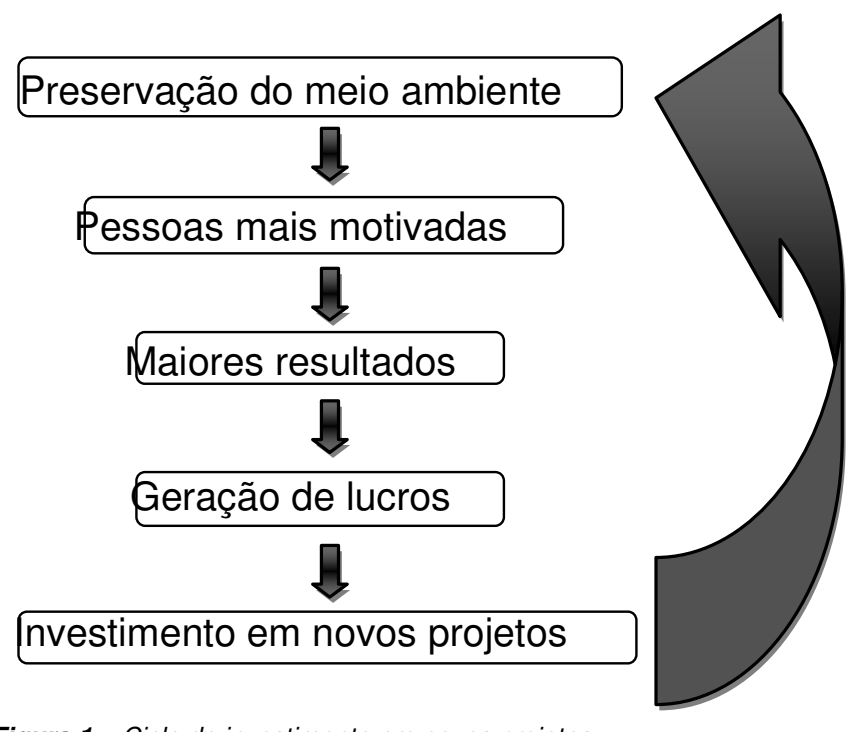

Fonte: Citação do E10, 2009.

Figura 1 - Ciclo de investimento em novos projetos 
Estas percepções, possivelmente, foram transmitidas pela cultura organizacional, que segundo Shein (apud TAVARES, 1996, p.2), é caracterizada por ser "o modelo dos pressupostos básicos, que determinado grupo tem inventado, descoberto ou desenvolvido no processo de aprendizagem para lidar com os problemas de adaptação externa e integração interna"; e quando são considerados válidos são transmitidos aos demais.

Seguindo este raciocínio, pode-se identificar na fala do E6 que, quando diz:

\section{"Essas iniciativas são de grande valor para o planeta".}

Apresenta uma visão semelhante à idéia de E2 acima descrita, sobre a necessidade de se pensar no bem-estar da sociedade e não individualmente. Essas falas foram marcantes para a confirmação da importância dada aos projetos socioambientais pelos entrevistados.

Com relação à implantação dos projetos socioambientais na organização, todos os entrevistados concordaram que é importante, alguns enfatizaram maior importância por se tratar de um hospital, que constantemente busca atender seus clientes de forma humanizada, como foi o caso de E7 e E9. Segundo Vecchiatti (2004), esta iniciativa deve acontecer individualmente, por meio da conscientização e sensibilização dos indivíduos da empresa. Cada um tem responsabilidade neste processo e toma consciência disso ao refletir sobre a vida dos futuros seres vivos e habitantes do planeta, principalmente seus descendentes.

Os entrevistados, quando interrogados se consideram o investimento em programas e projetos socioambientais um diferencial no mercado, afirmaram que é importante a implantação destes projetos não só para eles, mas para a sociedade, que valoriza a empresa que investe nesta iniciativa. Como afirmou E10, o investimento nos projetos eficazes: 
"Torna a empresa mais bem vista pelos seus consumidores e colaboradores, ocasionando então o que chamamos de publicidade gratuita (...) mais confiança desperta nas pessoas e elas irão optar pelo produto ou serviço da empresa que esteja promovendo bem-estar da sociedade".

Conforme Ashley; Coutinho; Tomei (2000), a prática da empresa e a mídia ressaltam exclusivamente a instrumentalização da responsabilidade social corporativa como auxílio na formação da reputação da empresa, a fim de adquirir competitividade no mercado.

Esta idéia é compartilhada pelo E6, que explica:

"Eu não compraria um produto caso soubesse que para fabricálo fosse necessário destruir de forma irrecuperável nossos recursos".

Assim como E6, E2 que acredita que:

"Atualmente as empresas que investem nesse tipo de iniciativa têm uma fatia maior no mercado (...) a sociedade valoriza bastante as empresas que se preocupam com o bem-estar do ser humano no futuro".

Dessa forma, pode-se dizer que, para os entrevistados, a implantação desses projetos é importante não só individualmente, mas também para a sociedade e para os clientes, conforme a percepção de E9.

Segundo o E10, estes projetos:

"Servem também para minimizar uma má visão da empresa, caso ela se utilize de recursos naturais como matéria prima".

Portilho (apud RUSCHEINSKY, 2008) complementa que as organizações, principalmente aquelas que geram um grande percentual de resíduos, estão promovendo uma redução nesta prática por meio de novos projetos e buscando 
evitar ao máximo o uso abusivo dos recursos naturais, em sua obra, alerta para os limites do consumo, a delimitação dos recursos naturais e a busca de uma racionalidade ambiental. Compartilha desta percepção o E4, quando diz que:

"É importante que todos desenvolvam a consciência ambiental de seus atos no dia-a-dia. No futuro, perceberemos a importância da tomada de consciência quando observamos a redução do número de crianças/adultos com doenças respiratórias, a redução de problemas urbanos resultantes de ações climáticas".

A preocupação com as gerações futuras também foi marcante nas falas dos entrevistados, como se pode verificar em E6:

"Essas iniciativas são de grande valor para o planeta que, sendo nossa casa e, caso não seja bem cuidado em suas relações sociais e capacidades ambientais, se tornará inabitável para os seres humanos".

E11 acrescenta ainda sobre a iniciativa de implantação de projetos socioambientais:

"Ampara algumas pessoas necessitadas e na parte ambiental preserva para gerações futuras".

Conforme assinalou Vecchiatti (2004, p. 93) que "à medida que o indivíduo se conscientiza da repercussão de seus atos nas gerações futuras e se preocupa com isso, desenvolve-se uma preocupação através das gerações capaz de enxergar uma responsabilidade comum. Para alcançar esse estado ideal, entretanto, o desenvolvimento cultural deve partir do reconhecimento dos cenários nos quais os atores sociais interagem, constroem espaços mudam os valores e os olhares sobre a vida em sociedade".

Esta preocupação também ocorre na fala de E10: 
"A importância para mim se baseia na participação de uma coisa que me motiva a fazer o bem e em longo prazo, pois estarei cuidando do meio ambiente para gerações futuras".

A importância da criação de projetos socioambientais apareceu em muitas falas em vários momentos das entrevistas, E1 acrescenta que:

"Além de ajudar o próximo, podemos preservar o meioambiente".

Semelhante a E1, E3 considera:

"Importante para conscientizar a sociedade em relação aos cuidados com o meio-ambiente e ser solidário com as pessoas que precisam".

Outro pensamento relevante que surgiu nas entrevistas foi a importância de participar dos projetos mesmo sem receber nenhum benefício, como enfatizou E4:

"Mesmo não percebendo os resultados e não recebendo nenhum benefício imediato, vejo que gosto de agir assim".

E7 também enfatiza a importância da conscientização, como pode verificar na fala:

"Conscientização de como vivemos hoje e como podemos melhorar o futuro (mesmo que não vamos nos beneficiar dele diretamente), é extremamente importante para mim".

Dessa forma, pode-se inferir que esse pensamento também advém da cultura, conceito criado para representar as qualidades de qualquer grupo humano específico, transmitidas de geração em geração (TAVARES, 1996). De acordo com Zanelli; Borges-Andrade; Bastos (2004, p. 410), "a cultura é um processo acumulativo que resulta do aprendizado obtido da totalidade da experiência histórica 
das gerações antecedentes. As peculiaridades desse processo podem restringir ou facilitar os comportamentos criativos e inovadores dos seres humanos".

Esse tema também englobou a questão dos valores transmitidos pela família, de acordo com E11:

"Acredito que a educação começa pela família, portanto, se estas atitudes iniciarem desde pequenos podemos mudar muita coisa ainda".

E12 concorda com E11 quando diz:

"A minha família sempre valorizou este tipo de iniciativa".

Após verificação e análise das falas acima citadas, pode-se interpretar que os entrevistados consideram importante a criação e implantação dos projetos socioambientais, alguns demonstram atuar de acordo com os valores repassados pela família e/ou educação; outros não têm o apoio da família, porém gostam de atuar pelo bem-estar da sociedade e preservação do meio ambiente. Porém, independentemente de como surgiu esta opção por apoiar e/ou participar deste tipo de iniciativa, os entrevistados demonstraram bastante interesse por esse tema e preocupação com o seu futuro e com o de seus descendentes.

Os entrevistados que demonstraram alguma resistência ao apoio a estas iniciativas, não relataram resistência diretamente aos projetos socioambientais, mas à forma com que são conduzidos e citaram outros fatores que interferem na condução destes projetos. Essas considerações reconhecidas pelos entrevistados como obstáculos culturais e/ou organizacionais à implantação dos projetos socioambientais serão apresentadas e discutidas nos subitens abaixo.

É importante ressaltar que para a análise das considerações abaixo não foram consideradas somente as falas dos entrevistados nas perguntas referentes a implantação, mas também em outras perguntas, nas quais os entrevistados demonstraram resistência a questões relacionadas a implantação de projetos socioambientais de ordem cultural e/ou organizacional. Dessa forma, buscou-se 
identificar formas de resistência de origem cultural e/ou organizacional que podem ter sido omitidas ou camufladas nas questões principais relacionadas à resistência.

\subsection{2 - Obstáculos culturais à implantação dos projetos socioambientais}

Dentre os fatores identificados pelos entrevistados como obstáculos culturais à implantação dos projetos socioambientais podem-se citar a falta de motivação e empenho dos participantes; a falta de interesse e a falta de participantes.

A apresentação e a análise dos obstáculos culturais nesta pesquisa foram baseadas nas considerações de Tavares (1996), para quem a cultura representa as qualidades de qualquer grupo humano específico, transmitidas de geração em geração e a cultura organizacional é manifestada por grupos de indivíduos que pertencem à organização, possuem padrões de comportamento, valores e crenças enraizados na empresa, de forma que os novos funcionários introduzem essas características de maneira natural.

Surgiram alguns aspectos culturais nas falas respondentes à pergunta sobre a importância da criação de projetos socioambientais para a família dos entrevistados. E4 afirma que sua família não tem iniciativa para a mudança, embora atuem quando Ihes é proposta alguma ação. Já E7 explica que embora sua família não participe de projetos socioambientais, acredita que eles consideram a criação desses projetos importante. No caso de E12, sua família sempre valorizou este tipo de iniciativa, mas atualmente não participa de nenhuma atividade deste tipo.

Delimitam-se três situações diferentes, a primeira, na qual não está claro na fala do entrevistado E4 que sua família apóia esta iniciativa, segundo a fala:

"A minha família também não está inserida em nenhum projeto. Buscamos agir de acordo com o que é proposto. Percebo que não temos a iniciativa de mudança”.

A segunda, na qual E7 sabe que sua família considera importante, porém não participam: 
"Dentro do meu núcleo familiar mais próximo, as pessoas não têm iniciativa para participar desses projetos. Mas eu sei que eles consideram a criação (não só a criação, mas também a implantação) importante".

E a terceira, na qual E12 afirma que a sua família sempre valorizou, mas atualmente não participa:

"A minha família sempre valorizou este tipo de iniciativa, mas atualmente não participa de nenhuma atividade deste tipo".

O desenvolvimento e amadurecimento de opinião, isto é, a maneira de pensar, influenciada inicialmente pela família, posteriormente, na escola, pode interferir na opinião da pessoa, o que também é considerado cultura, segundo Tavares (1996), a família é um grupo de pessoas com padrão semelhante de comportamento. Da mesma forma ocorre na escola com um grupo de amigos ou na organização, com um grupo de colegas de trabalho que se identificam.

Dessa forma, se pode inferir que estes entrevistados, em geral, seguem as mesmas atitudes herdadas da sua família. No caso de E4, embora declare que considera muito importante a criação de projetos socioambientais, não está engajada em nenhum, talvez porque seus pais não têm iniciativa de participar, segundo o que ela informou. Já E7 afirma que é extremamente importante para ele, porém, não participa de projetos socioambientais, gerando a interpretação de que há uma contradição nos ideais ou uma suposta resistência branca definida por Moura (2002), na qual a resistência é camuflada, isto é, a pessoa diz acreditar nas propostas e apoiar a iniciativa, porém não é proativa, fazendo com que o discurso não seja condizente com a prática. E12 considera importante criar, porém, para ele é mais importante manter os projetos funcionando, pois há casos em que os projetos são criados, entretanto não há uma continuidade dos mesmos.

A idéia de que cada um tem que fazer a sua parte para o sucesso dos projetos e de que todos devem lutar pelo bem comum, apareceu algumas vezes nas falas dos entrevistados. E6 e E11 falaram sobre a luta pelo bem comum, E6 comentou que: 
"Somente quando conhecermos e nos importarmos com a parcela da população mais carente e o valor de nossas reservas naturais poderemos crescer como nação".

E11, de outra forma, expressou as mesmas impressões:

"Se conseguirmos atingir a sociedade, fazendo com que a mesma fique engajada nos projetos socioambientais pelo bem comum, será de grande valia".

À medida que o indivíduo se conscientiza da repercussão de seus atos nas gerações futuras e se preocupa com isso, desenvolve-se uma preocupação através das gerações capaz de enxergar uma responsabilidade comum (VECCHIATTI, 2004).

Já E7 e E12, enfocaram a necessidade de cada um fazer a sua parte para que o objetivo seja alcançado e demonstraram não estar satisfeitos com a sociedade que, segundo eles, precisa ser mais atuante, pois não se mobiliza para fazer a diferença. E4 acrescenta que é necessário que a população se conscientize que seus atos podem trazer consequências para o meio ambiente.

Outro fator importante ressaltado pelos entrevistados foi a necessidade de conscientizar a sociedade sobre a importância dos projetos socioambientais. E3 declara que acha interessante a implantação de projetos socioambientais na sua organização e afirma que essa iniciativa auxilia no processo de tomada de consciência das necessidades do meio ambiente e da sociedade.

E4 compartilha desta opinião e acrescenta que:

"Todos devem rever a forma como agem".

E5 considera os colaboradores como pessoas que também precisam estar conscientes da sua contribuição para o mundo. E10 acrescenta que com estes projetos em funcionamento, as pessoas se tornam mais motivadas e conscientes da necessidade de preservação do meio ambiente e a integração com projetos voltados para o social. Segundo Vecchiatti (2004), a iniciativa deve acontecer individualmente, pois cada um tem a responsabilidade neste processo e toma 
consciência disso ao refletir sobre a vida dos futuros seres vivos e habitantes do planeta, principalmente seus descendentes e, na empresa, acontece por meio da conscientização e sensibilização dos indivíduos que trabalham nela.

Shein (apud TAVARES, 1996, p.2), define cultura organizacional como "o modelo dos pressupostos básicos, que determinado grupo tem inventado, descoberto ou desenvolvido no processo de aprendizagem para lidar com os problemas de adaptação externa e integração interna". Dessa forma, pode-se dizer que os entrevistados participam de um mesmo grupo, pois compartilham o mesmo pensamento e relatam necessidades parecidas, decorrentes, possivelmente, da cultura em que vivem e/ou da cultura organizacional adquirida nos grupos que faz parte dentro da organização.

Compartilham do mesmo pensamento E7 e E10, enfocando que o trabalho em um hospital deveria ser mais humanizado e menos mecânico; e que deveria ter mais projetos do que já tem, pois o que é feito é muito pouco perto das necessidades existentes. E1 acredita que os investimentos em programas socioambientais se tornam um diferencial para a organização no mercado e ressalta a importância da educação para uma nação, pois a melhor forma de promover os projetos é educando as pessoas e E11 afirma que se todos pudessem contribuir, os problemas atuais diminuiriam em concordância com E12 que ressalta que a ação conjunta faz a diferença, cada um fazendo sua parte já ajudaria muito.

De acordo com Zanelli; Borges-Andrade; Bastos (2004, p. 439), as culturas "são fenômenos espontâneos, conservadores e ocultos, de difícil identificação e alteração intencional" e não pode ser modificada, somente ampliada ou resignificada.

Outro fator pode ser observado na fala de E8, quando relata que:

"O que falta é um pouco de tempo por minha parte para as atividades".

É possível inferir que esta pode ser uma resposta para encobrir o baixo comprometimento, pois estabelece condições para sua participação, enquanto os demais já participam ou demonstram mais interesse em participar, segundo a análise das falas. E12, por exemplo, declara: 
"Eu já trabalho com isso fora da minha empresa, portanto, seria fácil de dedicar e pretendo atuar em todos, se fosse necessário, sempre que solicitado".

Dessa forma, E12 demonstra mais interesse e vontade em participar dos projetos que P8.

Quando analisadas as falas em resposta à pergunta se o entrevistado conhecia alguém (colega ou colaborador) que não apóia a iniciativa das empresas em adotar a implantação dos projetos socioambientais e os motivos pelos quais há esta oposição, surgiram diferentes fatores. E5 afirma que conhece uma pessoa que se opõe porque acha um desperdício de tempo e dinheiro; E6 acredita que sempre existem opiniões contrárias aos projetos; E7 complementa que não conhece ninguém contra, mas acredita que existem pessoas que são contra porque têm preguiça; E9 acredita que os que se opõem nunca participaram para saber o quanto é bom ajudar o próximo; E10 conhece uma pessoa que acredita que nada vai melhorar e esses problemas ambientais e sociais continuarão existindo; E11 acrescenta ainda que a oposição é desculpa para não participar e E12 acredita que estas pessoas que se opõem "não têm iniciativa; têm preguiça; desistem fácil dos objetivos; não conseguem parceiros e não levam os projetos para frente.

\subsection{3 - Obstáculos organizacionais à implantação dos projetos socioambientais}

Vários fatores foram citados pelos entrevistados como obstáculos organizacionais à implantação dos projetos socioambientais, entre eles: a falta de comunicação; a falta de organização; a falta de planejamento para realização dos projetos; a falta de acompanhamento; a falta de apoio por parte da Diretoria; a falta de recursos; os custos; a fraca ou liderança inexistente; o desvio no foco ou no objetivo do projeto; a má divulgação; a falha na comunicação dos resultados do projeto; o não estabelecimento de indicadores; a não liberação da chefia na participação dos projetos; a falta de objetivos dos projetos; a falta de incentivos e questões pessoais.

Foi escolhido como primeiro fator para análise a falta ou falha na comunicação, pois foi um fator marcante citado por vários entrevistados, quando 
interrogados sobre os fatores que podem impedir ou dificultar o processo de implantação dos projetos, como foi o caso do E1, E2, E6, E7, E9, E11 e E12, isto é, mais de $50 \%$ dos entrevistados consideram este fator relevante.

Claramente pode-se verificar na fala do E6, em resposta à pergunta sobre fatores impeditivos do processo:

"Desvio no foco ou objetivo do projeto, má divulgação causando pouco conhecimento e não envolvimento das pessoas no projeto, falha de comunicação da evolução do projeto e seus resultados causando o enfraquecimento da credibilidade e desistência dos participantes".

No caso do E8, encontrou-se sua opinião sobre a importância da comunicação quando respondeu à questão que tratou da conscientização e informação, enquanto E7 afirma que ainda não conhece todos os projetos, talvez por ter sido contratada a pouco tempo na empresa. Porém, E4 também afirma que não conhece muito de projetos socioambientais e já está na empresa há um ano e meio.

Dessa forma, pode-se inferir que este fator falha na comunicação, originalmente organizacional, pode desencadear desmotivação do participante do projeto, isto é, uma consequência também de caráter de formação de uma opinião inadequada sobre os projetos socioambientais, aumentando o teor do problema, como se verificou na fala de E6. Relacionado a isso também é importante citar a necessidade de que todos os indivíduos estejam engajados nos projetos, isto é, se sintam pertencentes ao grupo, o que gera um resgate da auto-estima individual e coletiva, fator crucial para o desenvolvimento humano com a sociedade (FARIA, 1999).

Conforme Motta (1998), a forma como é vista a mudança pode causar ou não resistência por parte dos envolvidos, pois a mudança pode ser encarada tanto como uma inovação benéfica para a solução de problemas, visando o desenvolvimento da empresa, isto é, com objetivos claros e expectativas de resultados eficazes como também como uma inovação inútil para o desenvolvimento da empresa. A implantação de novos projetos, como é o caso desta pesquisa, provoca mudanças nas organizações e segundo Chambel e Sousa (2007), estas ocorrem visando responder às ameaças, desafios e oportunidades. Por isso, deve-se ter a gestão da 
mudança como ponto chave neste processo, proporcionando um meio de transmitir detalhes da mudança a fim de torná-la atraente e aceita pelos colaboradores.

É fundamental a existência de um líder para o processo, conforme citam E6 e E9, quando falam que a liderança fraca ou inexistente é um fator que pode impedir ou dificultar o processo de implantação de projetos socioambientais. Zanelli; BorgesAndrade; Bastos (2004, p. 440) já afirmavam que "os dirigentes necessitam pensar como agentes de mudança" ao conduzirem o processo para atingirem o êxito que "depende vitalmente da coerência entre o discurso dos principais dirigentes e as práticas resultantes" (ZANELLI; BORGES-ANDRADE; BASTOS, 2004). Para E7, deveria existir um grupo responsável pelo acompanhamento e pela checagem dos projetos, caso contrário podem acabar não obtendo o sucesso desejado.

Os colaboradores, portanto, têm que conhecer detalhadamente o processo, para verificarem a utilidade da mudança e a liderança deve apoiar e auxiliar nesse processo. Bies e Shapiro (apud CHAMBEL; SOUSA, 2007) estudaram a reação dos colaboradores à presença ou ausência de mudança implantada pelo gestor e verificaram que a comunicação dos motivos das decisões pelo gestor é essencial para o aumento da aceitação da mudança. Além de comunicar os motivos da mudança, estes motivos têm de ser legítimos, a fim de evitar sentimentos de traição e desconfiança, conflitos e retaliações.

Da mesma forma acontecem também as questões de desvio no foco ou no objetivo do projeto, de falha na comunicação dos resultados e de má divulgação, todos relacionados ao fator comunicação, citado pelos entrevistados. A divulgação, citada por E10, caso o projeto gere bons resultados, ajuda no processo de implantação. Para E10, dessa forma, a empresa se torna:

"Mais bem vista pelos seus consumidores e colaboradores, ocasionando o que chamamos de publicidade gratuita".

Em contrapartida, continua E10, respondendo se há algo relacionado aos projetos pelo qual se opõe, afirma que:

"Sim, se eles não tiverem o devido planejamento e se a intenção deles for somente para melhorar a imagem da organização envolvida". 
Dessa forma, este entrevistado deixa nítida a importância da divulgação, porém esta não pode ser a meta principal da implantação dos projetos. Segundo Fontes (2003), a sustentabilidade é um conceito que se refere à possibilidade de um desenvolvimento sem prejuízo aos recursos existentes e atualmente, a empresa que visa somente o lucro e os processos rotineiros, está perdendo espaço no mercado; o ideal seria que a empresa fosse capaz de obter lucro sem sacrificar os recursos de suas pessoas, da comunidade e do planeta.

Kang (apud ASHLEY; COUTINHO; TOMEI, 2000, p.11) acrescenta que "as corporações são obrigadas a cumprir suas responsabilidades sociais e morais antes de tentarem maximizar seus lucros, sendo um meio eficiente e efetivo de controle social e uma base para a confiança nas relações humanas e organizacionais", enfocando que o conceito requer aplicabilidade das práticas, não reduzidas à racionalidade instrumental, mas a um novo modelo mental de relações sociais, econômicas e políticas. Dessa forma, a performance da empresa é avaliada pelo equilíbrio destas relações.

Para evitar que a falha na comunicação não configure como o obstáculo principal para a resistência dos envolvidos, é necessário que os projetos sejam descritos detalhadamente; tenham objetivos claros e expectativa de resultados; sejam bem divulgados no momento da implantação e sejam divulgados os resultados das ações, a fim de provocar envolvimento dos participantes nos projetos.

Com relação aos fatores falta de organização, citado pelo E1, E2 e E7 e falta de planejamento, citado pelo E1 e E10, são fatores interligados que também interferem no processo de implantação dos projetos socioambientais e podem ser também considerados obstáculos organizacionais à boa adesão dos envolvidos. Quando interrogados sobre seu apoio à iniciativa de implantação dos projetos, E7 afirma que:

"Se eles forem bem elaborados, eles podem ser implantados com sucesso"

E E5 foi bastante incisivo quando assinalou que:

"Tudo deve ter planejamento e deve ter seus dados mensurados (...) acho que é extremamente importante pessoas que trabalham nesses e em qualquer tipo de projeto, que conheçam um pouco de planejamento e indicadores". 
Tavares (1996) orienta que, para que a mudança aconteça, é necessário um estudo prévio dos elementos da cultura organizacional (valores, crenças, tabus, mitos, normas, comunicação formal e informal), pois eles condicionam e direcionam o comportamento das pessoas e grupos. Bastos (2001) complementa que, para se implantar novos programas em instituições de saúde, é fundamental tentar solucionar os problemas por meio de análise das características estruturais e histórias da organização. Os dois autores, adaptando-se para a presente pesquisa, falam de uma prévia organização dos projetos, conforme dizem os entrevistados citados. E, para se organizar o projeto, primeiramente, é necessário conhecer a realidade da organização, tanto das pessoas quanto de questões estruturais e estratégicas.

Quando interrogado há algo relacionado aos projetos socioambientais que se opõe, E2 afirma que não se opõe aos projetos, mas à maneira como conduzem e são organizados os projetos, segundo a fala:

"Diretamente aos projetos, pois a causa é nobre".

Verificou-se que E12 compartilha o mesmo pensamento de E2 e as falas são, inclusive, semelhantes:

"Não me oponho aos projetos, mas às pessoas que os conduzem de maneira errada".

E11 acrescenta que não concorda:

"Quando os projetos são escritos e tem uma idéia boa, mas na realidade não são aplicados ou são aplicados de maneira incorreta ou incompleta".

Para as questões pessoais foram consideradas as falas de E6 e E12 em relação à motivação e participação em projetos, em que E6 diz se sentir motivado em participar: 
"Desde que dentro da minha área de atuação e disponibilidade de horários para que eu pudesse me adequar e desenvolver bem as atividades que participasse".

E E12 explica que sua participação dependeria do que seria necessário para o desenvolvimento do projeto. Portanto, tem-se novamente nítida a necessidade de se esmiuçar cada detalhe do projeto, adequando o projeto às necessidades também dos participantes, a fim de atingir maior envolvimento.

Neste sentido acrescenta ainda E5 que:

"Precisaria saber exatamente o que seria esperado do projeto e o que iríamos utilizar".

E4 afirma que seu desempenho na organização pode ser afetado pela sua participação em projetos, pois:

"Inicialmente poderia afetar um pouco a produtividade, por falta de hábito. Posteriormente acredito que não será um problema".

Esse fator deve ser analisado pela gestão dos projetos socioambientais, de modo que não interfira ou que interfira pouco na produtividade do trabalho.

Segundo Zanelli; Borges-Andrade; Bastos (2004), o processo de mudança, considerado nesta pesquisa como a implantação de novos projetos, pressupõe a existência de ansiedade, comportamentos defensivos e resistência à mudança; por isso deve-se agir de acordo com o que é professado, a fim de estimular que os demais participantes da comunidade organizacional confiram credibilidades à realidade social em mudança. Dessa forma, tem-se que o processo deve ser bem organizado e não poderá haver informações contraditórias entre o que está planejado e o que realmente é feito.

Zanelli; Borges-Andrade; Bastos (2004) acrescentam ainda que para que haja motivação do empregado na empresa é necessário ficar atento a uma série de fatores, entre eles, a convergência entre os valores pessoais e organizacionais, caso contrário, pode haver diminuição da motivação. $O$ ideal é buscar o equilíbrio entre os 
valores pessoais e organizacionais. Pode-se verificar essa necessidade na fala de E12, ao responder se apoiava a iniciativa de implantação dos projetos:

"Apoio em parte, pois estes projetos têm de ser levados com muita seriedade, para se atingir os objetivos pré-estabelecidos. Quando há desvio disso, não concordo e não apóio".

E E2, quando fala que acredita que sua participação seria positiva para ele e para a organização:

"Só que ambos têm que percorrer o mesmo objetivo, de forma que todos se ajudem para fazer acontecer".

Moura (2002) alerta para o que ele chamou de resistência branca, isto é, uma resistência por parte dos envolvidos de maneira camuflada, na qual as pessoas aceitam e se mostram interessadas pelos projetos, mas não são proativos, atrasando o andamento das ações, o que não é esperado, mas pode acontecer também com as lideranças. Desta forma, o discurso é uma coisa e a prática é outra.

A falta de apoio por parte da diretoria foi considerada como mais um obstáculo à implantação de novos projetos, como se pode verificar na fala de E2 e E11. Segundo Wood (apud MONTEIRO; VENTURA; CRUZ, 1999), um dos fatores essenciais para uma mudança é o apoio da alta gerência para que seja um processo contínuo, planejado e executável em etapas.

Assim como se verificou que é importante o apoio da liderança e/ou do responsável aos participantes dos projetos, a gerência e diretoria, que também são lideranças, devem buscar motivar seus liderados, como em uma cadeia, no qual são transmitidas todas as informações a fim de atrair e motivar as lideranças dos projetos que, por fim, influenciarão nas opiniões dos colaboradores de ponta. E2 afirma que se opõe aos projetos socioambientais quando estes não têm apoio da organização para continuarem, marcando a importância do apoio dos superiores.

A falta de recursos e os custos configuraram como obstáculos organizacionais à implantação dos projetos. Estes fatores podem estar correlacionados, pois a falta de recursos pode estar relacionada aos elevados custos de implantação e manutenção de alguns projetos. De acordo com E12, os fatores impeditivos à implantação e que possivelmente levam ao fracasso dos projetos socioambientais 
são a falta de incentivos promovidos aos participantes e a não disponibilização de recursos para manutenção dos projetos.

Concordando com E12, E2 que afirma que a falta de recursos é um fator que pode impedir ou dificultar a implantação dos projetos, enquanto E5 citou somente os custos como único fator nesse processo. Uma consideração importante feita por E10 sobre essa questão é o ciclo iniciado com a implantação de um projeto, há a necessidade de se ter uma causa que motiva as pessoas envolvidas, pois isto aumenta o número de participações e os resultados são mais significativos, gerando lucros que podem ser utilizados como investimento em novos projetos.

Concordando com E10, o entrevistado E6 acrescenta que as organizações que possuem investimentos socioambientais são mais bem avaliadas pelos consumidores e por potenciais investidores, sendo esse um diferencial no mercado. E12 considera que:

"Todos os projetos seriam possíveis, de alguma forma, fazendo parcerias com outras empresas, caso não seja possível atingirmos os resultados somente com o apoio e recursos da própria empresa".

E10 e E12 demonstram grande interesse em melhorar o processo, pois acrescentam maneiras de driblar as dificuldades já existentes enquanto E4 afirma que sua organização não dispõe de uma grande quantidade de recursos para esses tipos de projetos e não acrescenta uma idéia de melhoria para o processo.

Conforme Schumpeter (1998), a postura empreendedora, que no caso desta pesquisa foi considerada como a implantação de novos projetos na empresa, é a busca de novas direções para se obter um diferencial competitivo e, para isso, o sucesso está na percepção e no aproveitamento das oportunidades de negócio, de utilizar recursos de uma nova forma e exercitar a criatividade, a fim de evitar custos e reaproveitar materiais sem ônus para a empresa.

Retomando a questão levantada por E12, sobre a falta de incentivos, segundo Pereira (1999), "o processo de mudança é sempre de auto-mudança, não é possível mudar uma pessoa se ela não quiser" e, compartilhando deste pensamento, Motta (1998) afirma que é necessário que a pessoa tenha um ganho em participar dos projetos, de forma que se ela obtiver incentivos aceitará melhor a novidade, o que remete novamente a questão já discutida sobre o apoio da liderança e da diretoria, 
embora alguns colaboradores considerem incentivos como auxílios para transporte, alimentação e bônus em dinheiro. Outro entrevistado, E10, citou também a questão de incentivos, no sentido de que é importante que as pessoas conheçam os benefícios das práticas destes projetos.

O fator falta de acompanhamento também merece bastante atenção, pois foi abordado por vários entrevistados, dentre eles E12 que opina que:

"É importante criar, mas é mais importante mantê-los. Em muitos casos há a criação, porém não há uma continuidade".

Este é um pensamento compartilhado também por E1, quando diz:

"Frequentemente deve ser avaliado para que eles permaneçam severos e justos a todos".

Dessa forma, E1 refere-se a importância do desenvolvimento e acompanhamento dos projetos.

Para E4, é importante que haja um acompanhamento desde o início, principalmente no momento da implantação, para que a mudança de atitude e postura sejam efetivas. Compartilham ainda destas ideias E2, E3, E5, E6, E7, E9, E10 e E11. Segundo Monteiro; Ventura; Cruz (1999), "toda mudança implica algum sacrifício e é sempre cercada por incertezas" e a resistência para o processo de mudança de cultura organizacional talvez não seja pelo fato da mudança em si, mas pela forma com que é gerenciada.

Uma consideração importante realizada pelo participante $\mathbf{E 1 2}$ merece destaque para finalizar esta análise da categoria "obstáculos organizacionais", pois reúne muitos dos fatores discutidos neste trabalho. $O$ entrevistado foi interrogado se conhecia algum colega ou colaborador que não apoiasse a iniciativa dos projetos socioambientais e os motivos pelos quais ele se opunha. E12 respondeu que sim e que:

"As justificativas são até plausíveis, pois alguns alegam que os projetos não funcionam porque as pessoas não têm iniciativa; têm preguiça; desistem fácil dos objetivos; não conseguem parceiros e não levam os projetos pra frente; com isso, perde-se a razão de continuar e desestimula os demais. $O$ ideal era ter um acompanhamento de tudo e propor melhorias para os projetos". 


\section{CONCLUSÕES}

A partir dos resultados apresentados, conclui-se que todos os entrevistados, representando uma parcela dos colaboradores do hospital, consideram importante a implantação de projetos socioambientais.

Alguns demonstraram mais interesse em participar dos projetos e maior envolvimento com as causas socioambientais, inclusive ressaltando que é essencial a criação e a implantação dos projetos por ser um hospital, no qual se espera um atendimento mais humanizado e colaboradores que pensem no bem-estar da sociedade e no futuro de seus descendentes.

Foram apresentados pelos entrevistados vários motivos considerados como obstáculos culturais e organizacionais que poderiam impedir ou dificultar o processo de implantação destes projetos. Dentre eles foram citados como principais a falta ou falha na comunicação; a falta de acompanhamento; a falta de motivação e interesse; a falta de recursos e investimentos; a falta de um responsável pelo projeto; o alto custo e a falta de apoio da Diretoria.

Analisando a opinião dos entrevistados, conclui-se que é necessário e possível implantar os projetos socioambientais e que, provavelmente, terá apoio dos participantes, pois a grande maioria demonstrou interesse em participar. Porém, será necessário tomar algumas providências antes da implantação dos projetos.

Primeiramente, seguindo as orientações dos entrevistados e com apoio da base teórica, os projetos socioambientais devem ser muito bem planejados e organizados. Após a criação do projeto, este deve ter objetivos claros e sensatos, que realmente sejam possíveis de serem realizados e não fiquem somente no papel. Tendo o projeto sido criado, estruturado e organizado em todos os detalhes, é necessário viabilizar quais os recursos necessários para a implantação e manutenção do projeto e o custo, se é viável ou não implantá-lo, de acordo com as necessidades da organização e os resultados que o projeto possa repercutir.

Após a definição dos detalhes estruturais do projeto e estratégicos para a organização, é viável verificar a aceitação dos colaboradores para tal projeto. Caso a aceitação seja satisfatória, é necessário envolver os participantes, enfocando incentivos para sua participação. É necessário promover ideias atraentes que chamem a atenção dos participantes. Além disso, segundo os relatos dos 
entrevistados, não basta somente se criar um projeto, mas é de grande importância realizar o acompanhamento do projeto, atualizando segundo os recursos disponíveis na empresa as necessidades da sociedade e o apoio dos colaboradores. Por isso, uma das questões levantadas pelos entrevistados foi a necessidade da existência de uma liderança responsável pelo acompanhamento do projeto; pela comunicação das ações e dos resultados das ações aos envolvidos e pelo bom andamento do projeto.

Outro fator relevante muito enfatizado pelos entrevistados foi a questão da comunicação e divulgação. Grande parte dos entrevistados alegou que a comunicação é crucial para o bom funcionamento e aceitação dos projetos e que atualmente não acontece de maneira satisfatória. É necessário também apresentar os resultados dos projetos e o alcance que poderão ter; o que é necessário para atingir os objetivos, dentre outros, a fim de envolvê-los e engajá-los no processo, de maneira clara e aberta, acessível a todos os interessados.

Por meio da análise dos depoimentos dos entrevistados, pode-se inferir que a maioria apóia a implantação de projetos socioambientais, inclusive considera muito importante essa iniciativa. Além disso, é interessante ressaltar que a maioria possui interesse e vontade em participar dos projetos, embora alguns ainda estabeleçam critérios para a participação e críticas com relação à maneira como são conduzidos.

Portando, os organizadores ou responsáveis pelos projetos devem atentar para as questões propostas pelos entrevistados, pois o sucesso dos projetos depende, em grande parte, do envolvimento e da participação de colaboradores voluntários. A opinião dos colaboradores foi de grande relevância para a confecção e desenvolvimento da pesquisa, pois acrescentou a visão dos próprios colaboradores e proporcionou também uma oportunidade de os mesmos contribuírem com ideias. 


\section{REFERÊNCIAS}

ASHLEY, Patricia Almeida; COUTINHO, Renata Buarque Goulart; TOMEI, Patricia Amélia. Responsabilidade Social Corporativa e Cidadania Empresarial: uma análise conceitual comparativa. In: ENANPAD, Rio, 2000.

BARDIN, L. Análise de conteúdo. Lisboa - Portugal. Ed 70, 3를. ed. 2004.

BASTOS, Marisa Antonini Ribeiro. A temática cultura organizacional nos estudos na área da saúde e da enfermagem. Revista Latino-am Enfermagem, 2001.

BAUMGARTEN, MAÍRA. Conhecimento, planificação e sustentabilidade. São Paulo Perspec., Jul 2002, vol.16, no.3, p.31-41. ISSN 0102-8839

BURSZTYN, M. (Org). Ciência, ética e sustentabilidade (2 $\left.{ }^{\mathrm{a}} e d.\right)$. São Paulo: Cortez, 2001.

CHAMBEL, Maria José e SOUSA, Luís. Aceitação da mudança e desempenho dos enfermeiros: A importância do cumprimento das obrigações por parte do hospital. Psicologia. [online]. 2007, vol.21, no.1 [citado 03 Abril 2009], p.177-200.

Disponível na World Wide Web:

http://www.scielo.oces.mctes.pt/scielo.php?script=sci_arttext\&pid=S0874-

$20492007000100009 \&$ Ing=pt\&nrm=iso $>$. ISSN 0874-2049.

FARIA, H. (Org.). Seminário Desenvolver-se com Arte. São Paulo: Instituto Pólis, 1999.

FONTES, Breno Augusto Souto-Maior. Sobre a sustentabilidade das associações voluntárias em uma comunidade de baixa renda. Tempo soc., Abr 2003, vol.15, no.1, p.159-189. ISSN 0103-2070

HERNANDEZ, J. M. C.; CALDAS, M. P. Resistência à mudança: uma revisão crítica. São Paulo: RAE Revista de Administração de Empresas, v. 41, n. 2, p. 3145, abr.jjun. 2001. 
LEAL, Anne Pinheiro; DA SILVA, Rosimeri Carvalho. Mudança organizacional e importância da influenciação dos atores. In: ENEGEP, 2000, São Paulo. Anais do XX ENEGEP, 2000.

MONTEIRO, Carmem Diva; VENTURA, Elvira Cruvinel \& DA CRUZ, Patrícia Nassif. Cultura e mudança organizacional: em busca da compreensão sobre o dilema das organizações. Caderno de Pesquisas em Administração, vol. 1, oo 8. São Paulo, 1999.

MOTTA. P. R. Transformação organizacional. A teoria e prática de inovar. Rio de Janeiro: Qualitymark, 1998.

MOURA, Gisela Garcia. Comportamentos de Resistência à mudança da média gerência diante da implantação da NBR ISO 9000. Florianópolis, UFSC, Programa de Pós-Graduação em Engenharia de Produção, 2002.

NEVES, José L. Pesquisa Qualitativa: características, usos e possibilidades. Caderno de Pesquisa em Administração, São Paulo, vol. 1, n.3, 2o sem.1996.

PEREIRA, M. J. B. Pressupostos da mudança. In: Na cova dos leões - o consultor como facilitador do processo decisório empresarial. São Paulo: Makron Books, 1999. Cap.1, p 3-12.

RICHARDSON, R. J. Pesquisa social: métodos e técnicas. 2. ed. São Paulo: Atlas, 1999.

ROCHA, Welington; BORINELLI, Márcio Luiz. Análise Estratégica de Cadeia de Valor: um estudo exploratório do segmento indústria-varejo. São Paulo: RCC Revista Contemporânea de Contabilidade, vol.1, n. 7, p. 145-165, jan./jun. 2007.

RUSCHEINSKY, Aloísio. Sustentabilidade ambiental, consumo e cidadania: a conjugação entre sustentabilidade, consumo e atores sociais. Sociologias, Porto Alegre, ano 10, № 19, 2008.

SERPA, Daniela Abrantes Ferreira; FOURNEAU, Lucelena Ferreira. Responsabilidade social corporativa: uma investigação sobre a percepção do 
consumidor. Revista de Administração Contemporânea, Rio de Janeiro: ANPAD, v. 11, n. 3, p. 83-103, Jul./ Set. 2007.

SILVA, Edna Lúcia da. Metodologia da pesquisa e elaboração de dissertação. 3. ed. rev. atual. - Florianópolis: Laboratório de Ensino a Distância da UFSC, 2001.

TANAKA, Oswaldo Y.; Melo, Cristina. Avaliação de Programas de Saúde do Adolescente- um modo de fazer. São Paulo: Edusp, 2001.

TAYRA, Flávio \& RIBEIRO, Helena. Modelos de indicadores de sustentabilidade, síntese e avaliação crítica das principais experiências. Saúde e Sociedade v.15, n.1, p.84-95, jan-abr 2006.

TAVARES, Fernanda Pereira. A cultura organizacional como instrumento de poder. Caderno de Pesquisas em Administração, vol. 1, nํ․ São Paulo, 1996.

VECCHIATTI, Karin. Três fases rumo ao desenvolvimento sustentável: do reducionismo à valorização da cultura. São Paulo Perspec., Set 2004, vol.18, no.3, p.90-95. ISSN 0102-8839

ZANELLI, José Carlos; BORGES-ANDRADE, Jairo Eduardo; BASTOS, Antônio Virgílio Bittencourt. Psicologia, organizações e trabalho no Brasil. Porto Alegre: Artmed, 2004. 


\section{APÊNDICES}

\section{Apêndice 1 - Roteiro de entrevista estruturada}

Cargo:

Idade:

Sexo:

Tempo de empresa:

1. O que você entende por projetos socioambientais?

2. Cite alguns projetos que você conhece que visem o desenvolvimento da sociedade e a preservação do meio-ambiente.

3. Você conhece os projetos socioambientais que já existem na sua organização?

4. Você apóia este tipo de iniciativa? Por quê?

5. Qual a importância, em sua opinião, da criação de projetos socioambientais para você?

6. Qual a importância, em sua opinião, da criação de projetos socioambientais para sua família?

7. Qual a importância, em sua opinião, da criação de projetos socioambientais para a sociedade?

8. Qual a importância, em sua opinião, do desenvolvimento e do acompanhamento desses projetos?

9. Você acha interessante a implantação de projetos socioambientais na organização onde você trabalha? Por que sim ou por que não?

10. Você acredita que investimento em programas e projetos voltados para a questão socioambiental se torna um diferencial para sua organização no mercado? Por quê? De que forma isso ocorreria, se você responder positivamente?

11. Quais projetos socioambientais seriam viáveis para a organização em sua opinião?

12. Você se sentiria motivado a participar destes projetos? Por quê?

13. Sua participação como voluntário (a) nesses projetos interferiria no desempenho de suas atividades?

14. De que forma sua participação interferiria em seu desempenho?

15. Você acredita que sua participação seria positiva para você e para sua organização?

16. Se projetos socioambientais fossem implantados na sua organização, em quais você imagina atuar?

17. Você se opõe a algo relacionado aos projetos socioambientais? Por quê?

18. Você conhece alguém (colega, colaborador) que não apóia esta iniciativa e os motivos pelos quais ele (a) se opõe?

19. Você acredita que seu superior imediato (chefe, coordenador, supervisor, etc.) apóia iniciativas desse tipo?

20. Quais os fatores que podem impedir ou dificultar o processo de implantação destes projetos?

21. Que fatores podem interferir positivamente neste processo de implantação?

22. De que forma você atuaria para auxiliar a sua organização no processo de implantação desses projetos? 


\section{Apêndice 2 - Resultados das entrevistas}

\section{DESCRIÇÃO DOS ENTREVISTADOS}

E1: Auxiliar Administrativo, 36 anos, Feminino, 4 anos.

E2: Psicóloga, 23 anos, Feminino, 3 anos.

E3: Estagiária, 21 anos, Feminino, 6 meses.

E4: Economista, 25 anos, Feminino, 1 ano e meio.

E5: Assistente de RH, 24 anos, Feminino, 6 meses.

E6: Analista da Qualidade Pleno, 37 anos, Masculino, 5 anos.

E7: Estagiária, 22 anos, Feminino, 15 dias.

E8: Assistente do cliente, 32 anos, Feminino, 1 ano.

E9: Auxiliar Administrativo, 33 anos, Feminino, 4 anos.

E10: Analista da Comunicação Social Sênior, 25 anos, Masculino, 2 anos.

E11: Técnico em Segurança do trabalho, 23 anos, Masculino, 3 anos e 3 meses.

E12: Técnico em Enfermagem, 25 anos, Masculino, 2 anos e 4 meses. 


\section{TRANSCRIÇÃO DAS ENTREVISTAS}

\section{Abaixo, seguem as perguntas formuladas para a entrevista $e$ as respostas dos entrevistados, numeradas de 1 a 12, correspondente ao número do entrevistado:}

\begin{tabular}{|c|c|}
\hline \multirow{12}{*}{$\begin{array}{l}1 \text { - O que você } \\
\text { entende por projetos } \\
\text { socioambientais? }\end{array}$} & $\begin{array}{l}\text { E1 - São projetos que tem por principal objetivo defender bens e direitos } \\
\text { sociais, relativos também ao meio-ambiente e ao patrimônio cultural. }\end{array}$ \\
\hline & $\begin{array}{l}\text { E2 - Projetos Socioambientais são projetos que visam o desenvolvimento da } \\
\text { sociedade em todos os sentidos, social, econômico, cultural, educacional e } \\
\text { outros e, simultaneamente, podem estar voltados para a preservação do } \\
\text { meio-ambiente. }\end{array}$ \\
\hline & $\begin{array}{l}\text { E3 - São projetos relacionados aos cuidados que a sociedade deve ter com o } \\
\text { meio-ambiente. }\end{array}$ \\
\hline & $\begin{array}{l}\text { E4 - Projetos que tenham por objetivo a preservação e a sustentabilidade do } \\
\text { meio ambiente, destacando os problemas socioambientais que serão } \\
\text { abordados, a eficácia das ações previstas e de que forma contribuirão para } \\
\text { transformar uma realidade. }\end{array}$ \\
\hline & $\begin{array}{l}\text { E5 - São projetos que visam beneficiar a comunidade e/ou trabalhar a } \\
\text { conscientização ambiental. }\end{array}$ \\
\hline & $\begin{array}{l}\text { E6 - São projetos que visam o crescimento organizacional pela interação } \\
\text { benéfica com a sociedade e o meio ambiente. }\end{array}$ \\
\hline & $\begin{array}{l}\text { E7 - São projetos que visam melhorar, de diversas maneiras, questões } \\
\text { ambientais e sociais. }\end{array}$ \\
\hline & $\begin{array}{l}\text { E8 - São projetos que são feitos para conscientização da sociedade e sobre o } \\
\text { meio ambiente. }\end{array}$ \\
\hline & $\begin{array}{l}\text { E9 - São projetos desenvolvidos por empresas, de acordo com as demandas } \\
\text { da sociedade, buscando atendê-las, desenvolvendo ações que supram suas } \\
\text { necessidades ou pelo menos amenize a necessidade social. }\end{array}$ \\
\hline & $\begin{array}{l}\text { E10 - São projetos que as empresas adotam para sanar uma necessidade } \\
\text { atual de todas as empresas de se integrarem com o ambiente e com a } \\
\text { sociedade em geral. Projetos que servem também para minimizar uma má } \\
\text { visão da empresa caso ela se utilize de recursos naturais como matéria prima } \\
\text { então são feitos projetos para que essa "culpa" seja minimizada e a atividade } \\
\text { fim da empresa não seja vítima de publicidade ruim para a empresa. }\end{array}$ \\
\hline & $\begin{array}{l}\text { E11 - É uma preocupação tanto com o amparo a sociedade num modo amplo } \\
\text { e com a preservação ambiental. }\end{array}$ \\
\hline & $\begin{array}{l}\text { E12 - São projetos que tem por objetivo pensar em melhorias para a } \\
\text { sociedade e para o meio em que ela vive. }\end{array}$ \\
\hline
\end{tabular}




\begin{tabular}{|c|c|}
\hline & E1 - Reciclagem e doações às instituições carentes. \\
\hline & $\begin{array}{l}\text { E2 - Voluntariado Luz (doações e visitas a instituições carentes) Programa de } \\
\text { Reciclagem (materiais e lixo), Projeto Sombra (adolescentes que passam o } \\
\text { dia no Hospital acompanhando todas a atividades de um colaborador } \\
\text { específico), Projeto de Informática (aulas de informática aberta a sociedade } \\
\text { para aprender as ferramentas básicas), Programa de Doadores de Sangue } \\
\text { (voluntários permanentes), Programas de economia de água e energia, } \\
\text { Programa de gestão de resíduos hospitalares. }\end{array}$ \\
\hline & $\begin{array}{l}\text { E3 - Reciclagem, Campanhas de Educação Ambiental e Campanhas de } \\
\text { Doações e Solidariedade. }\end{array}$ \\
\hline & $\begin{array}{l}\text { E4 - Não conheço muitos: Agenda Ambiental na Administração Pública (A3P); } \\
\text { Coleta Seletiva em minha comunidade; Biblioteca Digital da minha } \\
\text { organização (Projeto em que busca a disponibilidade na rede do máximo de } \\
\text { links para acesso a revistas eletrônicas) e o projeto implementado por mim no } \\
\text { meu setor: atualmente evitamos a cópia de documentos, escaneamos o } \\
\text { máximo de documentos, buscando a redução do consumo de papel. }\end{array}$ \\
\hline & $\begin{array}{l}\text { E5 - Ensino de informática em comunidades carentes, reciclagem, } 5 \mathrm{~S} \text {, } \\
\text { reflorestamento. }\end{array}$ \\
\hline 2 - Cite alguns & E6 - Junior Achievement, Coleta seletiva e Carbono Zero. \\
\hline $\begin{array}{l}\text { conhece que visem o } \\
\text { desenvolvimento da }\end{array}$ & $\begin{array}{l}\text { E7 - Coleta e reciclagem de lixo; Sonhar Acordado; Uso de material reciclado; } \\
\text { Plantação de árvores; Limpeza do lago Paranoá; etc. }\end{array}$ \\
\hline sociedade e a & E8-Greenpeace. \\
\hline meio-ambiente. & $\begin{array}{l}\text { E9 - Dentre vários projetos, destaco alguns da LAF - Empresa de Serviços } \\
\text { Hospitalares LTDA (Hospital Brasília), o Programa Em Dia com o Planeta - } \\
\text { cada internação equivale a uma árvore plantada em área de preservação } \\
\text { ambiental; Programa de Reciclagem - visa a segregação responsável feita } \\
\text { pelos próprios colaboradores, de materiais recicláveis, para um resultado } \\
\text { específico e recompensador; Bolsa de Estudos - investimento na educação } \\
\text { dos colaboradores, estimulando-os ao crescimento educacional, profissional e } \\
\text { no que diz respeito as oportunidades futuras dentro da empresa. }\end{array}$ \\
\hline & $\begin{array}{l}\text { E10 - Projetos de empresas que tem madeira como matéria prima, as } \\
\text { empresas fazem extração de madeira para produção de seus produtos, mas } \\
\text { ao mesmo tempo que ela extrai da natureza ela promove um reflorestamento } \\
\text { da área atingida. Projetos de integração da sociedade nas atividades fins da } \\
\text { empresa como projetos de integração social com menores carentes, } \\
\text { deficientes etc. Projetos também voltados para os próprios colaboradores da } \\
\text { empresa integrando a família dos colaboradores 'a empresa, como incentivos } \\
\text { aos estudos dos filhos, as melhores praticas de hábitos saudáveis e } \\
\text { integração de todos em projetos para beneficiar os mais carentes. }\end{array}$ \\
\hline & E11 - Reciclagem, doações em asilos, creches, orfanatos. \\
\hline & $\begin{array}{l}\text { E12 - Apoio a instituições carentes de diversas formas, com doações } \\
\text { materiais e de atenção; programas para promoção de saúde para } \\
\text { comunidades carentes; programas de reciclagem; programas de redução de } \\
\text { custos. }\end{array}$ \\
\hline
\end{tabular}




\begin{tabular}{|c|c|}
\hline \multirow{12}{*}{$\begin{array}{c}3 \text { - Você conhece os } \\
\text { projetos } \\
\text { socioambientais que } \\
\text { já existem na sua } \\
\text { organização? }\end{array}$} & E1 - Sim, as doações realizadas pelo Hospital a instituições carentes. \\
\hline & E2 - Sim, são estes que citei. Alguns já foram implantados, outros, ainda não. \\
\hline & E3 - Sim, Campanha do Agasalho. \\
\hline & E4 - Reciclagem de materiais e campanhas internas. \\
\hline & E5 - Reciclagem e Informática. \\
\hline & E6 - Sim, mas acho que poderiam ser melhor divulgados. \\
\hline & E7 - Acredito que não conheço todos ainda. \\
\hline & $\begin{array}{l}\text { E8 - No hospital existe um projeto em que é plantada uma árvore a cada } \\
\text { paciente que tem alta. }\end{array}$ \\
\hline & E9 - Sim. Todos os citados acima. \\
\hline & E10 - Sim. \\
\hline & E11 - Sim. \\
\hline & E12 - Sim, muitos deles eu já participo. \\
\hline
\end{tabular}




\begin{tabular}{|c|c|}
\hline \multirow{12}{*}{$\begin{array}{l}4 \text { - Você apóia este } \\
\text { tipo de iniciativa? }\end{array}$} & E1 - Sim, pois é um ato de caridade e demonstra amor ao próximo. \\
\hline & $\begin{array}{l}\text { E2 - Com certeza, é importante pois demonstra que não estamos sendo } \\
\text { egoístas ao pensar somente em benefício próprio, mas também em benefício } \\
\text { da comunidade e do meio-ambiente. }\end{array}$ \\
\hline & E3 - Sim, gosto de ajudar a quem precisa. \\
\hline & $\begin{array}{l}\text { E4 - Com certeza. É importante que tenhamos consciência ambiental dos } \\
\text { nossos atos no dia a dia. Dadas as condições climáticas em grandes } \\
\text { mudanças, o desperdício deve ser evitado, o reaproveitamento e a reciclagem } \\
\text { devem ser incentivados etc. }\end{array}$ \\
\hline & $\begin{array}{l}\text { E5 - Sim, sempre. Precisamos ter essa consciência de ajudar os outros e a } \\
\text { nós mesmos. }\end{array}$ \\
\hline & $\begin{array}{l}\text { E6 - Sim, pois essas iniciativas são de grande valor para o planeta que, } \\
\text { sendo nossa casa e, caso não seja bem cuidado em suas relações sociais e } \\
\text { capacidades ambientais, se tornará inabitável para os seres humanos. }\end{array}$ \\
\hline & $\begin{array}{l}\text { E7 - Sim, claro. Eu acredito que se eles forem bem elaborados, eles podem } \\
\text { ser implantados com sucesso. }\end{array}$ \\
\hline & $\begin{array}{l}\text { E8 - Sim, pois incentiva a sociedade a preservar nosso meio ambiente e que } \\
\text { o hospital está se preocupando com o nosso meio ambiente. }\end{array}$ \\
\hline & E9 - Sim, é de notável importância. \\
\hline & $\begin{array}{l}\text { E10 - Sim, pois tais práticas só trazem benefícios a todos os envolvidos. O } \\
\text { meio ambiente por estar sendo preservado, as pessoas envolvidas por se } \\
\text { sentirem mais motivadas e realizadas fazendo o bem para o meio ambiente e } \\
\text { a sociedade; e com essa motivação, o trabalho produz mais resultados dando } \\
\text { mais resultados para as empresas e gerando lucros. Lucro esse que } \\
\text { possibilita que uma maior porcentagem possa ser investida na realização de } \\
\text { novos projetos. É um ciclo que pode crescer por si só. Desde que todos os } \\
\text { envolvidos façam sua parte. }\end{array}$ \\
\hline & $\begin{array}{l}\text { E11 - Sim, pois ampara algumas pessoas necessitadas e na parte ambiental } \\
\text { preserva para as gerações futuras. }\end{array}$ \\
\hline & $\begin{array}{l}\text { E12 - Apoio em parte, pois estes projetos têm de ser levados com muita } \\
\text { seriedade, para se atingir os objetivos pré-estabelecidos. Quando há desvio } \\
\text { disso, não concordo e não apoio. }\end{array}$ \\
\hline
\end{tabular}




\begin{tabular}{|c|c|}
\hline & E1 - Além de ajudar o próximo podemos preservar o meio-ambiente. \\
\hline & $\begin{array}{l}\text { E2 - Para mim, os projetos socioambientais têm grande importância já que, } \\
\text { além de trabalhar com isso dentro e fora da organização, faz parte do que } \\
\text { valorizo nas pessoas. }\end{array}$ \\
\hline & $\begin{array}{l}\text { E3 - Importante para conscientizar a sociedade em relação aos cuidados com } \\
\text { o meio-ambiente e ser solidário com as pessoas que precisam. }\end{array}$ \\
\hline & $\begin{array}{l}\text { E4 - Eu acho muito importante, mas não estou engajada em projetos } \\
\text { socioambientais. Eu procuro mudar os meus hábitos como uma forma de } \\
\text { aderir a esses projetos. Mesmo não percebendo os resultados e não } \\
\text { recebendo nenhum benefício imediato por aderir, vejo que gosto de agir } \\
\text { assim. }\end{array}$ \\
\hline 5 - Qual a & $\begin{array}{l}\text { E5 - Criamos pessoas com outra percepção de trabalhar para preservação do } \\
\text { meio ambiente e o respeito à sociedade. }\end{array}$ \\
\hline & $\begin{array}{l}\text { E6 - Acho uma iniciativa inteligente que traz nossa interação e melhor } \\
\text { compreensão sobre os problemas e soluções existentes. }\end{array}$ \\
\hline $\begin{array}{l}\text { socioambientais para } \\
\text { você? }\end{array}$ & $\begin{array}{l}\text { E7 - Conscientização de como vivemos hoje e como podemos melhorar o } \\
\text { futuro (mesmo que não vamos nos beneficiar dele diretamente), é } \\
\text { extremamente importante para mim. }\end{array}$ \\
\hline & E8 - Até o momento não foi possível dar minha opinião nestes projetos. \\
\hline & $\begin{array}{l}\text { E9 - É uma iniciativa considerável e brilhante, que demonstra o desejo de se } \\
\text { ter um mundo melhor. O cuidado e preocupação expressos através de ações } \\
\text { diferenciadas que trazem impacto positivo para uma vida melhor. }\end{array}$ \\
\hline & $\begin{array}{l}\text { E10 - A importância para mim se baseia na participação de uma coisa que me } \\
\text { motiva a fazer o bem e a longo prazo pois estarei cuidando do meio ambiente } \\
\text { para gerações futuras. }\end{array}$ \\
\hline & E11 - Promover a consciência nas pessoas de que a mudança parte de nós. \\
\hline & $\begin{array}{l}\text { E12 - É importante criar, mas é mais importante mantê-los. Em muitos casos, } \\
\text { há a criação, porém não há uma continuidade. }\end{array}$ \\
\hline
\end{tabular}




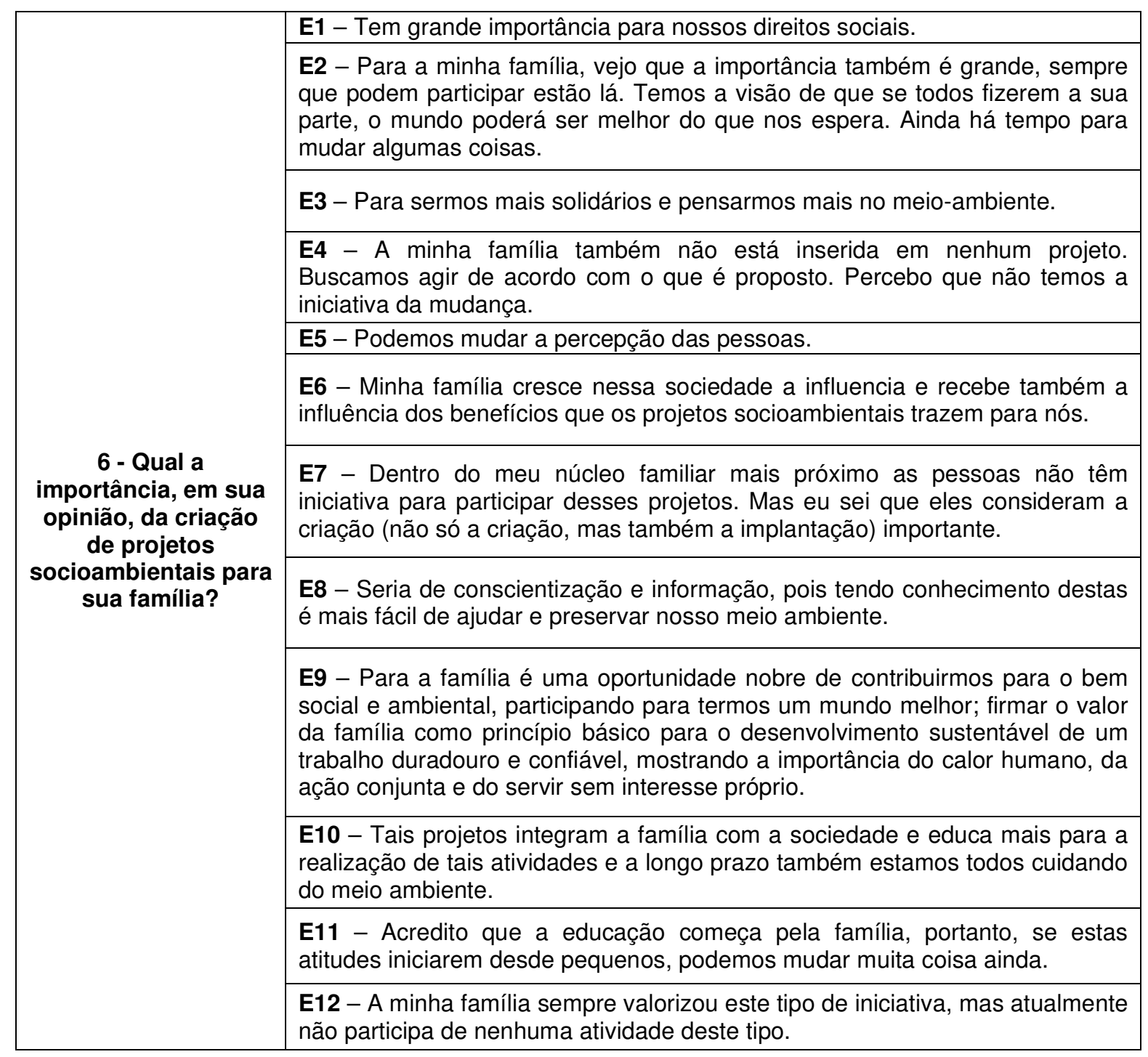




\begin{tabular}{|c|c|}
\hline & $\begin{array}{l}\text { E1 - Para melhorar os patrimônios culturais que estão voltados para a } \\
\text { sociedade. }\end{array}$ \\
\hline & $\begin{array}{l}\text { E2 - Para a sociedade, principalmente as mais carentes, garante em parte } \\
\text { que as pessoas que não têm uma condição de vida muito favorável possam } \\
\text { desfrutar de alguns auxílios, principalmente na área da educação e da renda } \\
\text { familiar. }\end{array}$ \\
\hline & $\begin{array}{l}\text { E3 - Para conscientizar a sociedade sobre o meio ambiente e sobre a } \\
\text { importância de ajudar ao próximo. }\end{array}$ \\
\hline & $\begin{array}{l}\text { E4 - Para a sociedade, é importante que todos desenvolvam a consciência } \\
\text { ambiental de seus atos no dia a dia. No futuro, perceberemos a importância } \\
\text { da tomada de consciência quando observarmos a redução do número de } \\
\text { crianças/adultos com doenças respiratórias, a redução de problemas urbanos } \\
\text { resultantes de ações climáticas etc. }\end{array}$ \\
\hline & E5 - Gerar pessoas capazes de doar um pouco de si para os outros. \\
\hline $\begin{array}{l}\text { importância, em sua } \\
\text { opinião, da criação } \\
\text { de projetos }\end{array}$ & $\begin{array}{l}\text { E6 - Acredito que somente quando conhecermos e nos importarmos com a } \\
\text { parcela da população mais carente e o valor de nossas reservas naturais } \\
\text { poderemos crescer como nação. }\end{array}$ \\
\hline $\begin{array}{l}\text { socioambientais para } \\
\text { a sociedade? }\end{array}$ & $\begin{array}{l}\text { E7 - Eu diria que é fundamental! Mas infelizmente ainda são poucos os que } \\
\text { pensam assim. A maioria acha "uma idéia legal", mas não se mobilizam para } \\
\text { fazer a diferença. }\end{array}$ \\
\hline & $\begin{array}{l}\text { E8 - Não foi possível ajudar neste sentido pois não estou vinculada a nenhum } \\
\text { grupo socioambiental. }\end{array}$ \\
\hline & $\begin{array}{l}\text { E9 - Ver surgir uma sociedade com interesses mútuos, valores iguais, bem } \\
\text { comum. Uma sociedade totalmente interessada a doar-se na ação do servir, } \\
\text { visando o melhor para o próximo. }\end{array}$ \\
\hline & $\begin{array}{l}\text { E10 - A educação de uma forma geral, a conscientização para o bem estar da } \\
\text { sociedade e a preservação do meio ambiente para mantermos o mesmo para } \\
\text { o futuro. }\end{array}$ \\
\hline & $\begin{array}{l}\text { E11 - Se conseguirmos atingir a sociedade, fazendo com que a mesma fique } \\
\text { engajada nos projetos socioambientais pelo bem comum, será de grande } \\
\text { valia. }\end{array}$ \\
\hline & $\begin{array}{l}\text { E12 - Se cada um fizer a sua parte, fará a diferença. A sociedade precisa ser } \\
\text { mais atuante neste sentido. }\end{array}$ \\
\hline
\end{tabular}

8-Qual a importância, em sua
E1 - Freqüentemente deve ser avaliado para que eles permaneçam severos e justos a todos. 


\begin{tabular}{|c|c|}
\hline \multirow[t]{11}{*}{$\begin{array}{c}\text { opinião, do } \\
\text { desenvolvimento e } \\
\text { do acompanhamento } \\
\text { desses projetos? }\end{array}$} & $\begin{array}{l}\text { E2 - Estes projetos não podem ficar somente no papel, precisam de atuação } \\
\text { e sua elaboração deve acontecer de acordo com o desenvolvimento da } \\
\text { própria sociedade e acompanhados freqüentemente para verificar se } \\
\text { realmente as metas serão atingidas. }\end{array}$ \\
\hline & $\begin{array}{l}\text { E3 - O desenvolvimento e o acompanhamento são importantes para manter a } \\
\text { sociedade informada e sempre em contato com os cuidados necessários ao } \\
\text { meio-ambiente e com as pessoas que precisam. }\end{array}$ \\
\hline & $\begin{array}{l}\text { E4 - A importância do desenvolvimento desses projetos está na } \\
\text { conscientização da população de que os seus atos podem ter conseqüência } \\
\text { sobre o meio ambiente. E essas conseqüências afetam diretamente a vida de } \\
\text { todos, apesar de não apresentarem efeito imediato. O acompanhamento, } \\
\text { inicialmente, deverá ser intenso, pois, para que a mudança de hábito seja } \\
\text { efetiva, é necessário que haja a cobrança dos organismos que } \\
\text { implementaram o projeto. Além disso, é preciso que seja feita a revisão da } \\
\text { estratégia de comunicação e de abordagem para se tenha o } \\
\text { comprometimento dos participantes. }\end{array}$ \\
\hline & $\begin{array}{l}\text { E5 - Tudo deve ter planejamento e deve ter seus dados mensurados e } \\
\text { medidos para ver a eficiência e a eficácia do projeto. Acho que é } \\
\text { extremamente importante pessoas que trabalham nesses e em qualquer tipo } \\
\text { de projeto, que conheçam um pouco de planejamento e indicadores. }\end{array}$ \\
\hline & $\begin{array}{l}\text { E6 - O desenvolvimento de projetos permite o estudo das inter-relações em } \\
\text { todos os níveis de complexidade existentes, traçando a problemática e } \\
\text { cenários futuros casos não nada seja feito. O acompanhamento é } \\
\text { fundamental para que as ações definidas no desenvolvimento sejam } \\
\text { implementadas e haja uma avaliação da eficácia dessas ações. }\end{array}$ \\
\hline & $\begin{array}{l}\text { E7 - Eu acho que deveria existir sempre um grupo responsável pelo } \\
\text { acompanhamento desses projetos porque a maioria tem realmente a "idéia } \\
\text { legal" mas como não tem alguém responsável pela "checagem", eles acabem } \\
\text { não tendo muito sucesso. }\end{array}$ \\
\hline & $\begin{array}{l}\text { E8 - Seria mesmo de conscientização e informação para tratar bem nosso } \\
\text { meio ambiente. }\end{array}$ \\
\hline & $\begin{array}{l}\text { E9 - Sem o acompanhamento não há resultados significativos e não podemos } \\
\text { conhecer em que podemos melhorar. }\end{array}$ \\
\hline & $\begin{array}{l}\text { E10 - A tecnologia e a informação fazem com que tudo se desenvolva mais } \\
\text { rápido e os resultados podem ser maiores, desde que sejam acompanhados } \\
\text { de uma forma eficaz e especializada para que esse crescimento dos } \\
\text { resultados e da expansão dos projetos realmente funcional. }\end{array}$ \\
\hline & $\begin{array}{l}\text { E11 - Sem desenvolvimento e o acompanhamento as coisas ficam somente } \\
\text { no papel e não vão para frente, por isso, deve-se sempre buscar atualização } \\
\text { nesse processo e engajamento de todos. }\end{array}$ \\
\hline & $\begin{array}{l}\text { E12 - Os projetos precisam de acompanhamento contínuo para } \\
\text { aperfeiçoamento dos objetivos e possíveis atualizações. É importante também } \\
\text { para aprendermos cada vez mais. }\end{array}$ \\
\hline \multirow{2}{*}{$\begin{array}{c}9 \text { - Você acha } \\
\text { interessante a } \\
\text { implantação de } \\
\text { projetos } \\
\text { socioambientais na }\end{array}$} & $\begin{array}{l}\text { E1 - Sim, pois podemos ajudar tanto a um funcionário quanto a um cliente no } \\
\text { Hospital. }\end{array}$ \\
\hline & $\begin{array}{l}\text { E2 - Com certeza, porque o hospital preza pelo atendimento humanizado e } \\
\text { recebe diariamente pacientes (sociedade) que valorizam este tipo de } \\
\text { iniciativa. }\end{array}$ \\
\hline
\end{tabular}




\begin{tabular}{|c|c|}
\hline \multirow{10}{*}{$\begin{array}{l}\text { organização onde } \\
\text { você trabalha? Por } \\
\text { que sim ou porque } \\
\text { não? }\end{array}$} & $\begin{array}{l}\text { E3 - Sim, para que os colaboradores tenham também a consciência das } \\
\text { necessidades do meio-ambiente e da sociedade. }\end{array}$ \\
\hline & $\begin{array}{l}\text { E4 - Como passamos a maior parte do tempo útil de nossos dias no trabalho, } \\
\text { é necessário que a organização tenha essa preocupação. A participação das } \\
\text { organizações é fundamental para a tomada de consciência de todos de que } \\
\text { devem rever a forma como agem. }\end{array}$ \\
\hline & $\begin{array}{l}\text { E5 - Sim, são pessoas que também precisam estar conscientes da sua } \\
\text { contribuição para o mundo. }\end{array}$ \\
\hline & $\begin{array}{l}\text { E6 - Sim, pois a organização é o um importante meio para conscientizarmos } \\
\text { as pessoas de maneira construtiva e prática. }\end{array}$ \\
\hline & $\begin{array}{l}\text { E7 - Sim. Por se tratar de um hospital, que está constantemente lidando com } \\
\text { o sofrimento do outro, deveria ser mais humanizado. Percebo que muitos têm } \\
\text { o trabalho mecânico e por isso eu acho que é importante a existência dos } \\
\text { projetos para que os colaboradores se mobilizem com questões sociais. }\end{array}$ \\
\hline & $\begin{array}{l}\text { E8 - Sim, pois demonstra que a organização está preocupada com o futuro, } \\
\text { em dar uma qualidade de vida e contribuir na preservação e no cuidado com o } \\
\text { meio ambiente. }\end{array}$ \\
\hline & $\begin{array}{l}\text { E9 - Por ser um hospital, com certeza, é preciso manter um ambiente mais } \\
\text { humanizado, demonstrar a preocupação com os outros. Acredito que faça } \\
\text { toda a diferença. }\end{array}$ \\
\hline & $\begin{array}{l}\text { E10 - Sim, pois as pessoas se sentem mais motivadas e isso educa para a } \\
\text { necessidade da conscientização da preservação do meio ambiente e a } \\
\text { integração com projetos voltados para o social. }\end{array}$ \\
\hline & $\begin{array}{l}\text { E11 - Com certeza, todas as empresas podem pensar em implantar projetos } \\
\text { socioambientais de acordo com a sua realidade. }\end{array}$ \\
\hline & $\begin{array}{l}\text { E12 - É claro. Um hospital do porte do meu deveriam ter mais projetos do que } \\
\text { já tem. A necessidade da sociedade é constante, embora ajudemos quando é } \\
\text { possível, nunca é o suficiente. }\end{array}$ \\
\hline
\end{tabular}




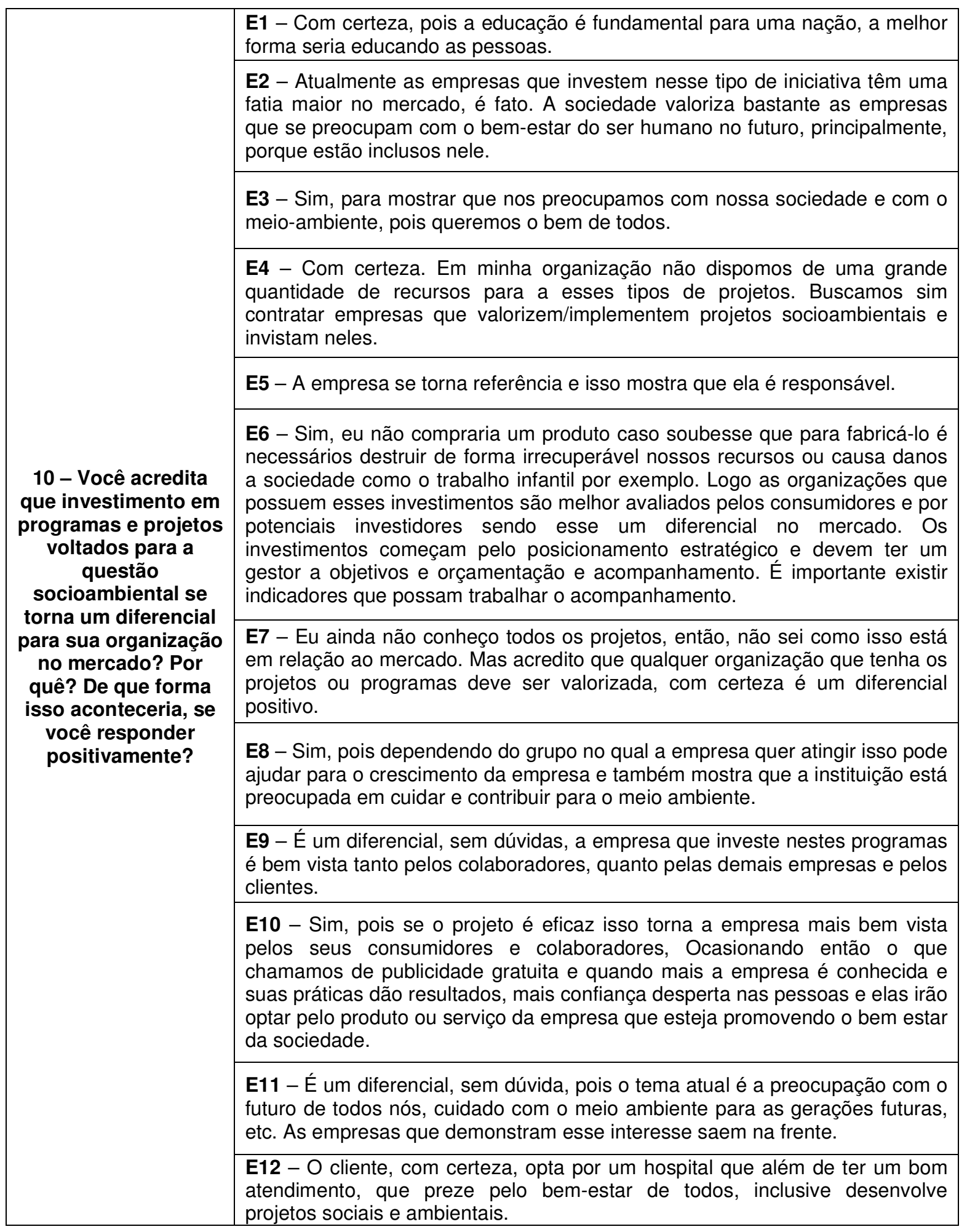




\begin{tabular}{|c|c|}
\hline \multirow{12}{*}{$\begin{array}{l}11 \text { - Quais projetos } \\
\text { socioambientais } \\
\text { seriam viáveis para a } \\
\text { organização, em sua } \\
\quad \text { opinião? }\end{array}$} & E1 - Principalmente reciclagem de lixo e materiais. \\
\hline & $\begin{array}{l}\text { E2 - Por ser um hospital, acredito que a reciclagem de materiais e as doações } \\
\text { e visitas realizadas nas instituições carentes. }\end{array}$ \\
\hline & E3 - Continuar com as campanhas e com a plantação de árvores. \\
\hline & $\begin{array}{l}\text { E4 - Projetos que busquem a redução de consumo de papel, a contratação de } \\
\text { empresas que valorizem/implementem projetos socioambientais e invistam } \\
\text { neles. }\end{array}$ \\
\hline & $\begin{array}{l}\text { E5 - Reciclagem, 5S, auxílio a creches e asilos, apoio a centros } \\
\text { especializados para pessoas com doenças complexas. }\end{array}$ \\
\hline & $\begin{array}{l}\text { E6 - Projetos relacionados ao nosso core business, ou seja, voltados a } \\
\text { atenção e prevenção de doenças evitáveis nas comunidades ou escolas } \\
\text { carentes próximas. A coleta de materiais pode também contar com oficinas de } \\
\text { reciclagem desses materiais. }\end{array}$ \\
\hline & E7 - Reciclagem e uso de material reciclado (papel, por exemplo). \\
\hline & E8 - Reciclagem e doações. \\
\hline & E9 - Reciclagem de materiais, visitas a asilos e creches escolares. \\
\hline & $\begin{array}{l}\text { E10 - Projetos que integrassem a vizinhança e as famílias. E projetos de } \\
\text { segregação do lixo e reciclagem de lixo não orgânico. }\end{array}$ \\
\hline & E11 - Reciclagem, apoio a instituições carentes, plantação de árvores. \\
\hline & $\begin{array}{l}\text { E12 - Todos os projetos seriam possíveis, de alguma forma, fazendo } \\
\text { parcerias com outras empresas, caso não seja possível atingirmos os } \\
\text { resultados somente com o apoio e recursos da própria empresa. }\end{array}$ \\
\hline
\end{tabular}




\begin{tabular}{|c|c|}
\hline \multirow{12}{*}{$\begin{array}{c}12 \text { - Você se sentiria } \\
\text { motivado a participar } \\
\text { destes projetos? Por } \\
\text { quê? }\end{array}$} & E1 - Sim, pois o projeto de reciclagem realmente funcionaria. \\
\hline & $\begin{array}{l}\text { E2 - Com certeza. Desde pequena me envolvo nestes tipos de trabalhos e } \\
\text { gosto muito. }\end{array}$ \\
\hline & E3 - Sim, porque gosto. \\
\hline & $\begin{array}{l}\text { E4 - Sim. Por acreditar que seja importante a participação de todos para } \\
\text { benefício de todos. Além de achar que estou cumprindo o meu dever de } \\
\text { cidadã. }\end{array}$ \\
\hline & $\begin{array}{l}\text { E5 - Sim, gosto de trabalhos voluntários, doar um pouco de mim para } 0 \\
\text { próximo. }\end{array}$ \\
\hline & $\begin{array}{l}\text { E6 - Sim, desde que dentro da minha área de atuação e disponibilidade de } \\
\text { horários para que eu pudesse me adequar e desenvolver bem as atividades } \\
\text { que participasse. }\end{array}$ \\
\hline & $\begin{array}{l}\text { E7 - Sim, este é um projeto fácil de se manter e não custa nada participar. } \\
\text { Fora que o pouco que eu estaria fazendo, eu sei que faz grande diferença. }\end{array}$ \\
\hline & $\begin{array}{l}\text { E8 - Sim, porque gosto de me envolver com grupos que tenham objetivos que } \\
\text { possam trazer algo bom e importante para as pessoas ou ambiente. }\end{array}$ \\
\hline & E9 - Para estes projetos, sempre estou disponível. \\
\hline & $\begin{array}{l}\text { E10 - Sim, pois me sinto mais motivado e feliz em ajudar de alguma forma o } \\
\text { meio ambiente e a sociedade e podendo participar de tais projetos em meu } \\
\text { trabalho fica mais fácil e viável de participar mais intensamente. }\end{array}$ \\
\hline & $\begin{array}{l}\text { E11 - Sim, muito. Já até participo de alguns. É importante para mim, sinto que } \\
\text { cumpri parte da minha responsabilidade. Se todos pudessem contribuir, } \\
\text { diminuiríamos muitos dos problemas atuais. }\end{array}$ \\
\hline & E12 - Sim, sempre motivado, luto pelo bem-estar de todos. \\
\hline
\end{tabular}




\begin{tabular}{|c|c|}
\hline \multirow{12}{*}{$\begin{array}{l}13 \text { - Sua participação } \\
\text { como voluntário (a) } \\
\text { nesses projetos } \\
\text { interferiria no } \\
\text { desempenho de suas } \\
\text { atividades? }\end{array}$} & E1 - Não interferiria. \\
\hline & $\begin{array}{l}\text { E2 - Interferiria no bom sentido, pois cada dia eu seria uma nova pessoa, } \\
\text { buscando cada vez mais ajudar ao próximo. }\end{array}$ \\
\hline & E3 - Sim, fico mais motivada. \\
\hline & $\begin{array}{l}\text { E4 - Nos tipos de projetos que citei acima, não. Até porque já fazem parte da } \\
\text { minha rotina de trabalho. }\end{array}$ \\
\hline & E5 - Depende do que seria necessário para o desenvolvimento do projeto. \\
\hline & E6 - Sim. \\
\hline & $\begin{array}{l}\text { E7 - Não, eu já costumo fazer isso fora da organização, então não teria } \\
\text { problema em fazer pela organização que estou. }\end{array}$ \\
\hline & E8 - Como disse anteriormente não foi possível fazer parte deste grupo. \\
\hline & $\begin{array}{l}\text { E9 - Sim, de maneira positiva, seria uma pessoa melhor, sabendo que estou } \\
\text { fazendo minha parte para ajudar os outros. }\end{array}$ \\
\hline & E10 - Sim, creio que me sentiria mais motivado e produziria mais. \\
\hline & E11 - Não, já participo de alguns. \\
\hline & $\begin{array}{l}\text { E12 - Com certeza, precisamos disso para sermos pessoas diferentes e mais } \\
\text { humanas. }\end{array}$ \\
\hline
\end{tabular}




\begin{tabular}{|c|c|}
\hline \multirow{12}{*}{$\begin{array}{l}14 \text { - De que forma } \\
\text { sua participação } \\
\text { interferiria em seu } \\
\text { desempenho? }\end{array}$} & E1 - Não interferiria. \\
\hline & $\begin{array}{l}\text { E2 - Poderia colocar em prática algumas coisas aprendidas com os projetos } \\
\text { socioambientais nas minhas atividades diárias no setor, por exemplo: iniciar } \\
\text { segregando o papel e o plástico no meu setor, com meus colegas. }\end{array}$ \\
\hline & E3 - Fico mais feliz. \\
\hline & $\begin{array}{l}\text { E4 - Inicialmente, poderia afetar um pouco a produtividade, por falta de } \\
\text { hábito. Posteriormente acredito que não será um problema. }\end{array}$ \\
\hline & $\begin{array}{l}\text { E5 - Claro que não me tomaria o dia inteiro, mas precisaria saber exatamente } \\
\text { o que seria esperado do projeto e o que iríamos utilizar. }\end{array}$ \\
\hline & $\begin{array}{l}\text { E6 - Ele aumentaria devido ao bem que eu sentiria em ajudar o próximo e o } \\
\text { meio ambiente. }\end{array}$ \\
\hline & $\begin{array}{l}\text { E7 - Acredito que não interferiria no meu desempenho, talvez eu passaria a } \\
\text { ficar mais próxima do grupo que participa dos projetos. }\end{array}$ \\
\hline & E8 - Interferiria em poder informar mais e ajudar para um bom resultado. \\
\hline & E9 - Seria uma pessoa mais feliz podendo ajudar os demais. \\
\hline & E10 - Me sentiria mais motivado. \\
\hline & E11 - Aumentaria minha auto-estima, em saber que posso ajudar os outros. \\
\hline & E12 - Atuaria em meu trabalho de maneira mais motivada. \\
\hline
\end{tabular}




\begin{tabular}{|c|c|}
\hline \multirow{12}{*}{$\begin{array}{l}15 \text { - Você acredita } \\
\text { que sua participação } \\
\text { seria positiva para } \\
\text { você e para sua } \\
\text { organização? }\end{array}$} & E1 - Sim, com certeza. \\
\hline & $\begin{array}{l}\text { E2 - Acredito. Só que ambos têm que percorrer o mesmo objetivo, de forma } \\
\text { que todos se ajudem para fazer acontecer. }\end{array}$ \\
\hline & E3 - Sim, é muito bom fazer o bem aos outros e ver o resultado disso. \\
\hline & $\begin{array}{l}\text { E4 - Sim. Na verdade a participação de todos poderá acrescentar muito aos } \\
\text { projetos que poderiam ser implementados, pois todos têm como contribuir. }\end{array}$ \\
\hline & $\begin{array}{l}\text { E5 - Sim. Todos nós crescemos, a empresa fica reconhecida e assim ela } \\
\text { cresce e eu me desenvolvo também. }\end{array}$ \\
\hline & E6-Sim. \\
\hline & $\begin{array}{l}\text { E7 - Sim. Pelo fato de me inteirar mais com as pessoas e podermos juntos ter } \\
\text { um melhor aproveitamento. }\end{array}$ \\
\hline & $\begin{array}{l}\text { E8 - Sim, pois quanto mais pessoas melhor é, pois o grupo se fortalece e } \\
\text { cresce. }\end{array}$ \\
\hline & E9 - Sim, precisamos disso. \\
\hline & E10 - Com certeza. \\
\hline & E11 - A participação de todos é importante, me sinto na obrigação de ajudar. \\
\hline & $\begin{array}{l}\text { E12 - A ação conjunta faz a diferença, cada um fazendo sua parte já ajudaria } \\
\text { muito. }\end{array}$ \\
\hline
\end{tabular}




\begin{tabular}{|c|c|}
\hline \multirow{12}{*}{$\begin{array}{l}16 \text { - Se projetos } \\
\text { socioambientais } \\
\text { fossem implantados } \\
\text { na sua organização, } \\
\text { em quais você } \\
\text { imagina atuar? }\end{array}$} & E1 - Na reciclagem, nas doações e visitas às instituições carentes. \\
\hline & $\begin{array}{l}\text { E2 - Já participo de alguns como reciclagem, visitas e doações a instituições } \\
\text { carentes. }\end{array}$ \\
\hline & E3 - Continuaria participando das campanhas lançadas no hospital. \\
\hline & $\begin{array}{l}\text { E4 - Eu iria priorizar os que fossem diretamente relacionados às atividades } \\
\text { que desempenho atualmente. }\end{array}$ \\
\hline & $\begin{array}{l}\text { E5 - Acho que eu teria que participar de quase todos, não só por causa da } \\
\text { área em que estou alocada, mas porque eu gosto também. }\end{array}$ \\
\hline & E6 - Nos projetos sociais. \\
\hline & $\begin{array}{l}\text { E7 - Coleta de material (exemplo: agasalho ou comida) para doação; } \\
\text { reciclagem e uso de material reciclado; visitas institucionais; seja para levar as } \\
\text { doações ou para fazer companhia para "velhinhos", por exemplo. }\end{array}$ \\
\hline & $\begin{array}{l}\text { E8 - Como já tem, o que falta é um pouco de tempo por minha parte para as } \\
\text { atividades. }\end{array}$ \\
\hline & E9 - Gosto de ajudar, independente de como for. \\
\hline & E10 - Todos. \\
\hline & E11 - Todos, se possível. \\
\hline & $\begin{array}{l}\text { E12 - Eu já trabalho com isso fora da minha empresa, portanto, seria fácil me } \\
\text { dedicar e pretendo atuar em todos, se fosse necessário, sempre que } \\
\text { solicitado. }\end{array}$ \\
\hline
\end{tabular}




\begin{tabular}{|c|c|}
\hline \multirow{12}{*}{$\begin{array}{c}17 \text { - Você se opõe a } \\
\text { algo relacionado aos } \\
\text { projetos } \\
\text { socioambientais? } \\
\text { Por quê? }\end{array}$} & E1 - Não. \\
\hline & $\begin{array}{l}\text { E2 - Não me oponho diretamente aos projetos, pois a causa é nobre, porém } \\
\text { me oponho à forma com que são organizados ou quando estes não têm apoio } \\
\text { da organização para que continuem. }\end{array}$ \\
\hline & E3 - Não. \\
\hline & $\begin{array}{l}\text { E4 - Aparentemente não. Eu não conheço muito de projetos socioambientais } \\
\text { para responder essa questão de maneira precisa. }\end{array}$ \\
\hline & E5 - Não. \\
\hline & $\begin{array}{l}\text { E6 - Sim. Quando eles não buscam a autonomia dos segmentos onde se } \\
\text { inserem causando uma dependência dos mesmos, não buscando o } \\
\text { desenvolvimento desses segmentos. }\end{array}$ \\
\hline & E7 - Não. \\
\hline & E8 - Não. \\
\hline & E9 - Não, gosto muito deste tipo de trabalho. \\
\hline & $\begin{array}{l}\text { E10 - Sim, se eles não tiverem o devido planejamento e se a intenção deles } \\
\text { forem somente para melhorar a imagem da organização envolvida. }\end{array}$ \\
\hline & $\begin{array}{l}\text { E11 - Não. Só não concordo quando os projetos são escritos e tem uma boa } \\
\text { idéia, mas na realidade não são aplicados ou são aplicados de maneira } \\
\text { incorreta ou incompleta. }\end{array}$ \\
\hline & $\begin{array}{l}\text { E12 - Não me oponho aos projetos, mas as pessoas que os conduzem de } \\
\text { maneira errada. }\end{array}$ \\
\hline
\end{tabular}




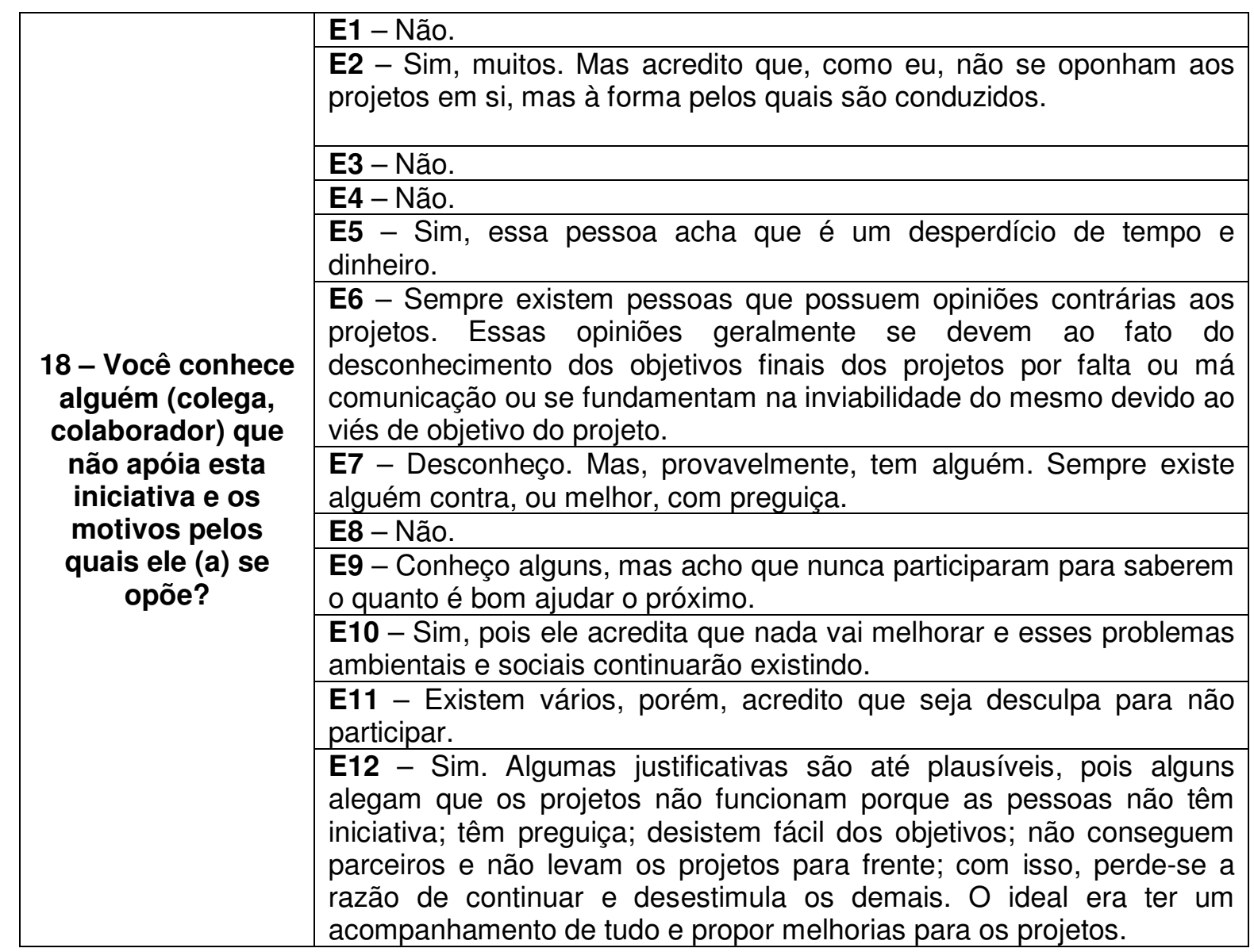




\begin{tabular}{|c|c|}
\hline \multirow{12}{*}{$\begin{array}{l}19 \text { - Você acredita } \\
\text { que seu superior } \\
\text { imediato (chefe, } \\
\text { coordenador, } \\
\text { supervisor, etc.) } \\
\text { apóia iniciativas } \\
\text { desse tipo? }\end{array}$} & E1 - Sim. \\
\hline & E2 - Sim, muitas das ideias partem dela. \\
\hline & E3 - Sim e muito. \\
\hline & E4 - Sim. Algumas ideias foram dele. \\
\hline & $\begin{array}{l}\text { E5 - Sim. A empresa ainda é jovem e se preocupa com a responsabilidade } \\
\text { social, e todos os gestores buscam conscientizar os seus subordinados. }\end{array}$ \\
\hline & E6 - Sim. \\
\hline & E7 - Acredito que sim. \\
\hline & E8 - Parece que sim. \\
\hline & E9 - Sim, pois ele demonstra e atua junto. \\
\hline & E10 - Acredito que sim. \\
\hline & E11 - Sim, bastante. \\
\hline & E12-Apóia sempre que possível. \\
\hline
\end{tabular}




\begin{tabular}{|c|c|}
\hline \multirow{12}{*}{$\begin{array}{l}20 \text { - Quais os fatores } \\
\text { que podem impedir } \\
\text { ou dificultar o } \\
\text { processo de } \\
\text { implantação destes } \\
\text { projetos? }\end{array}$} & $\begin{array}{l}\text { E1 - A falta de comunicação, a falta de organização e falta de planejamento } \\
\text { para a realização dos projetos. }\end{array}$ \\
\hline & $\begin{array}{l}\text { E2 - Os fatores principais, em minha opinião, são: falta de organização, falta } \\
\text { de acompanhamento, falta de apoio por parte da Diretoria, falta de recursos e, } \\
\text { muitas vezes, a comunicação é falha. }\end{array}$ \\
\hline & E3 - Falta de motivação e interesse. \\
\hline & E4 - A falta de empenho dos participantes. \\
\hline & E5 - Custos. \\
\hline & $\begin{array}{l}\text { E6 - Pouca ou liderança fraca, desvio no foco ou objetivo do projeto, má } \\
\text { divulgação causando pouco conhecimento e não envolvimento das pessoas } \\
\text { no projeto, falha de comunicação da evolução do projeto e seus resultados } \\
\text { causando enfraquecimento da credibilidade e desistência dos participantes. } \\
\text { Não estabelecimento ou inadequação de indicadores de acompanhamento. }\end{array}$ \\
\hline & $\begin{array}{l}\text { E7 - Desorganização; falta de comunicação e de divulgação e projetos muito } \\
\text { difíceis, seja pela distância de onde será feito ou pelo próprio serviço. }\end{array}$ \\
\hline & E8 - Falta de pessoas que queiram fazer parte do grupo. \\
\hline & $\begin{array}{l}\text { E9 - Quando não há um líder, quando não dão continuidade aos projetos, } \\
\text { quando a comunicação é falha. }\end{array}$ \\
\hline & E10 - Falta de planejamento e falta de motivação nas pessoas envolvidas. \\
\hline & $\begin{array}{l}\text { E11 - Comunicação falha, falta de objetivos, falta de apoio da Diretoria, } \\
\text { liberação da chefia em alguns setores. }\end{array}$ \\
\hline & $\begin{array}{l}\text { E12 - Projetos sem objetivos, falha na comunicação, sem incentivos e } \\
\text { recursos fazem com que o projeto fracasse. }\end{array}$ \\
\hline
\end{tabular}




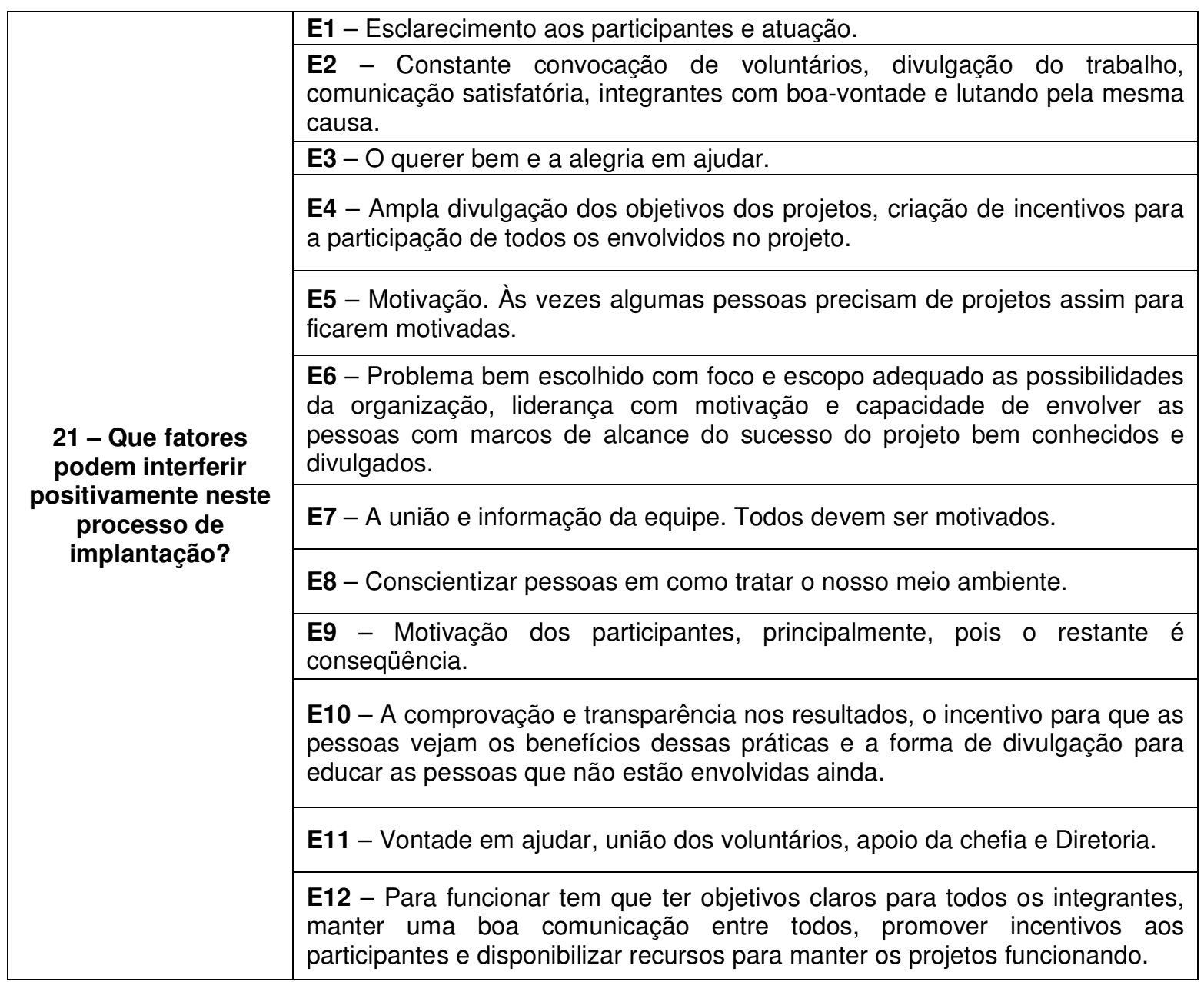




\begin{tabular}{|c|c|}
\hline \multirow{12}{*}{$\begin{array}{c}22 \text { - De que forma } \\
\text { você atuaria para } \\
\text { auxiliar a sua } \\
\text { organização no } \\
\text { processo de } \\
\text { implantação desses } \\
\text { projetos? }\end{array}$} & $\begin{array}{l}\text { E1 - Buscaria estar sempre informada dos projetos que estariam } \\
\text { acontecendo. }\end{array}$ \\
\hline & $\begin{array}{l}\text { E2 - Seria porta-voz das informações e atuaria divulgando o trabalho a fim de } \\
\text { conseguir cada vez mais voluntários para o grupo. }\end{array}$ \\
\hline & E3 - Apoiando e participando. \\
\hline & $\begin{array}{l}\text { E4 - Eu poderia propor algumas ideias de projetos, divulgar para todos os } \\
\text { envolvidos no projeto e incentivar a participação de todos. }\end{array}$ \\
\hline & E5 - No que fosse necessário. \\
\hline & E6 - Com a avaliação dos projetos e participando em sua implantação. \\
\hline & $\begin{array}{l}\text { E7 - Gostaria de participar desde a partir de pesquisa na organização e fora } \\
\text { dessa para saber qual a demanda e no desenvolvimento do projeto e, o mais } \\
\text { importante, na divulgação dele. }\end{array}$ \\
\hline & E8 - Em dar informação e ajudar no corpo-a-corpo, etc. \\
\hline & E9 - De todas as formas possíveis. \\
\hline & $\begin{array}{l}\text { E10 - Atuaria com o que faço no trabalho, com um melhor estudo sobre a } \\
\text { melhor forma de divulgação e motivação das pessoas para que participem de } \\
\text { algum projeto proposto e ajudaria na disseminação dos melhores resultados } \\
\text { para comprovação da eficácia e dos benefícios da participação nos projetos. }\end{array}$ \\
\hline & E11 - Atuaria na divulgação e participando de todos os projetos, se possível. \\
\hline & E12 - Na divulgação, na criação de projetos, na participação dos projetos. \\
\hline
\end{tabular}

